\title{
JUODASIS KUBAS: PIRMINIŲ FORMŲ MORFOLOGIJA IR FENOMENAS
}

\author{
Kęstutis Lupeikis \\ Architektūros katedra, Vilniaus Gedimino technikos universitetas, \\ Pylimo g. 26/Trakug. 1, LT-01132 Vilnius, Lietuva \\ El.paštaskestl@takas.lt \\ Iteikta 20091008
}

\begin{abstract}
Santrauka. Pastaruoju metu, šalia kitų reiškinių, šiuolaikinèje architektūroje vyksta pirminių formų panaudojimo renesansas. Ši procesą lemia priešprieša formaliam dekonstrukciniam laužymui, įmantrumui, daugžodžiavimui. Pirminių minimalistinių formų raišką šiuolaikinèje architektūroje formuoja šios vertybès: paprastumas, o ne įmantrumas; elegantiškumas, santūrumas, o ne arogantiškumas; dvasingumas, o ne pragmatizmas; esmingumas, o ne smulkmeniškumas; koncentracija, o ne išsibarstymas. Ši vertybinẻ skalè lemia specifinius architektūrinès raiškos tikslus ir prioritetus: su „mažiau“ siekiama „daugiau“, paprastomis priemonèmis siekiama tobulumo, pragmatizme, racionalizme siekiama dvasingumo, poezijos. Neretai pirminių formų panaudojimas sukelia prieštaringas diskusijas visuomenèje, tačiau net oponentai neneigia jų įtaigumo ir paveikumo, nes tai leidžia artèti prie tikrųjų vertybių, esmès, o viešai reiškiamas nuomonių pliuralizmas savaime yra demokratiškos visuomenės požymis.

Straipsnyje aptariami ịvairūs pirminių formų morfologijos šiuolaikinėje architektūroje aspektai ir sritys, išskiriami kraštutiniai, charakteringi atvejai, atspindintys platų tikslų ir prioritetų diapazoną. Prokuratūrų pastato „Juodojo kubo“ Vilniuje pavyzdžiu siekiama atskleisti pirminių formų morfologijos ir jų fenomeno esminius aspektus.
\end{abstract}

Reikšminiai žodžiai: pirminè forma, paprastumas, minimalizmas, morfologija, fenomenas, metamorfozè.

\section{Ivadas}

Jau senųjų kultūrų architektūriniame palikime aiškiai matomas tobulumo ir harmonijos siekis, kuris dažnai išreiškiamas per išskirtinai paprastas formas. Paprastumo siekiai akivaizdžiai išryškèjo dar daugelio senųjų civilizacijų bei vèlesnių epochų architektūriniame palikime. Paprastumo idejjos yra gajos nuo pat žmonijos aušros ir nepriklauso nuo vietos bei laiko. Jos gali būti siejamos su amžinųjų vertybių, idealų paieška ir labai gerai atsispindi įvairių epochų aiškių, o kartu paprastų bei tobulų formų, taip pat idealių, geometrinių struktūrų paieškose.

Paprastumo estetika yra paplitusi ir laike, ir erdvèje nuo senųjų amžių iki dabarties, nuo Japonijos iki Amerikos, îskaitant ir Azijos, Afrikos bei Europos žemynus. Skirtinguose regionuose pasitaiko labai daug bendrumų turinčių minimalistinès raiškos objektų ar net visiškai identiškų formų. Stebètinas pirminių for- mų, tokių kaip piramidè, ypač laiptuotoji, paplitimas nesusisiekiančiose Afrikos ir Amerikos žemynuose. Tai liudija tam tikrą lakoniškos raiškos fenomenalumą.

Pirminių geometrinių formų panaudojimas šiuolaikinèje architektūroje, kad ir keista, susilaukia išskirtinio dèmesio, lyginant su istorinès architektūros pavyzdžiais. $\mathrm{O}$ juk atrodo, kad dabarties visuomenè yra ne tokia konservatyvi, mačiusi visko. Netapo išimtimi ir administracinis Prokuratūrų pastatas ,Juodasis kubas“ Rinktinès gatveje Vilniuje. Šis pastatas sukèlè prieštaringus jausmus ir vertinimus tiek tarp profesionaliu architektų, menininkų, tiek visuomeneje, stimuliavo ivairias diskusijas spaudoje, interneto tinklalapiuose. Apie ji kalba ir maži, ir dideli, ir seni. Vienų jis vertinamas labai neigiamai, klijuojamos įvairios etiketès, kartais ir necenzūrinès, išliejama tulžis ant prokuroru, kitų, priešingai, priimamas besąlygiškai ir palydimas 
susižavejjimo šūksniais. Vaikams Lietuvos prokuratūrų pastato langai asocijuojasi su „pleistriukais“. Apie „Juodąji kubą“ daug rašè ir Lietuvos, ir užsienio spau$\mathrm{da}$, internetiniai tinklalapiai, kur atsispindi tam tikras tendencingumas - arba pozityvus, arba negatyvus. Tai, kad šiam statiniui nèra abejingų, verčia kalbèti apie tam tikrą jo išskirtinumą, fenomeną, bent jau Lietuvos architektūros kontekste. Nors eteryje sklando daug ịvairių nuomonių apie ši pastatą, vis tik nebuvo pateiktas visapusiškas ,Juodojo kubo “ pristatymas, neatskleistos jo meninès ypatybès. Tai inspiravo išsamiau apžvelgti Ł̇vairius šio objekto sukūrimo ir realizacijos, pirminių formų morfologijos aspektus.

\section{Pirminių geometrinių formų jèga ir ịtaigumas}

Paprastumo siekis, noras išgryninti formą ar mintị - neapibrèžtas reiškinys tiek laiko, tiek erdvès, tiek geografijos atžvilgiu. Paprastumo sąvoka apima tiek dvasinę, tiek materialiąją egzistencijos dimensijas. Paprastumas - koncentruota mąstymo, gyvenimo būdo išraiška, igaunanti ritualizuotą pavidalą arba materialią, apčiuopiamą formą. Paprastumas - mąstymo būdas, kurio raiška mene, kartu ir architektūroje igauna minimalias formas, kurios išreiškia tobulybès siekí, išsilaisvinimą nuo perdètos detalizacijos, smulkmeniškumo, kur kiekvienas segmentas, forma ir netgi lokalūs elementai kuria išgrynintą, išlaisvintą formos ir minties absoliutą, kur forma tampa ideja, o idèja vèlgi materializuojama, lengvai suvokiama, bet ne verbaliniu būdu, o kontempliuojant materialų jos ¡̇kūnijimą. Paprastumas, neturintis apibrèžtų ribų tiek chronologiniu, tiek geografiniu požiūriu, yra reiškinys, veikiau reiškinių sistema su aibe kintančių dimensijų, telpantis tiek $\mathfrak{i}$ sakralaus, tiek $\mathfrak{i}$ buitinio interpretavimo rèmus.

Paprastumo siekis turi ilgą istoriją, tai nèra pastarųjų metų ar net dešimtmečių atradimas. Paprastumas nèra vientisas reiškinys, o tuo labiau stiliaus apibūdinimas, tai veikiau kvazisistema, apimanti tiesiog enciklopedinị kiekị reiškinių - nuo civilizacijų priešaušrio iki šių dienų (chronologiniu aspektu) ir nuo ikikolumbinès Amerikos iki Japonijos ar Europos (geografiniu aspektu).

Paprastumas, grynumas, aiškumas, lakoniškumas, geometriškumas, pirminès formos - pagrindiniai minimalistinès raiškos mene ir architektūroje požymiai. Jie yra būdingi ir Senovès Egipto piramidems, ir Kaabos šventyklai, ir daugeliui kitu istorinès archi- tektūros pavyzdžių, nepaisant konkretaus formos pobūdžio (1 pav.).

Forma - kodèl be jos negalima apsieiti? Terminas „forma“ reiškia išvaizdą, pavidalą, kitaip tariant, tai bet kokio apimtinio paviršiaus vizualinè charakteristika. J. Grinius teigia: „Forma yra mūsų suvokimo ir pažinimo pagrindas. Per formą intelektas suvokia daiktų esmę. Forma leidžia pažinti ne tik esminius esybiu ir daiktu skirtumus, bet taip pat konkrečias ir individualias jų ypatybes" (Grinius 2002: 18). Dailëje ir architektūroje forma dažniausiai yra apibūdinama kaip kompozicijos išraiškos priemonių visuma, ir per ją reiškiasi harmonizuojančios kompozicijos priemonès. Architektūroje forma siejama su jos tektonišku$\mathrm{mu}$, taigi ji yra lyg ir visus kompozicijos elementus bei veiksnius jungianti substancija ir kartu pati yra kompozicijos priemonè.

Norint ką nors parodyti, atlikti bet kokị veiksmą, ịkūnyti, materializuoti bet kokią idejąa, visuomet kyla klausimas, kaip tą padaryti, kokias naudoti priemo-
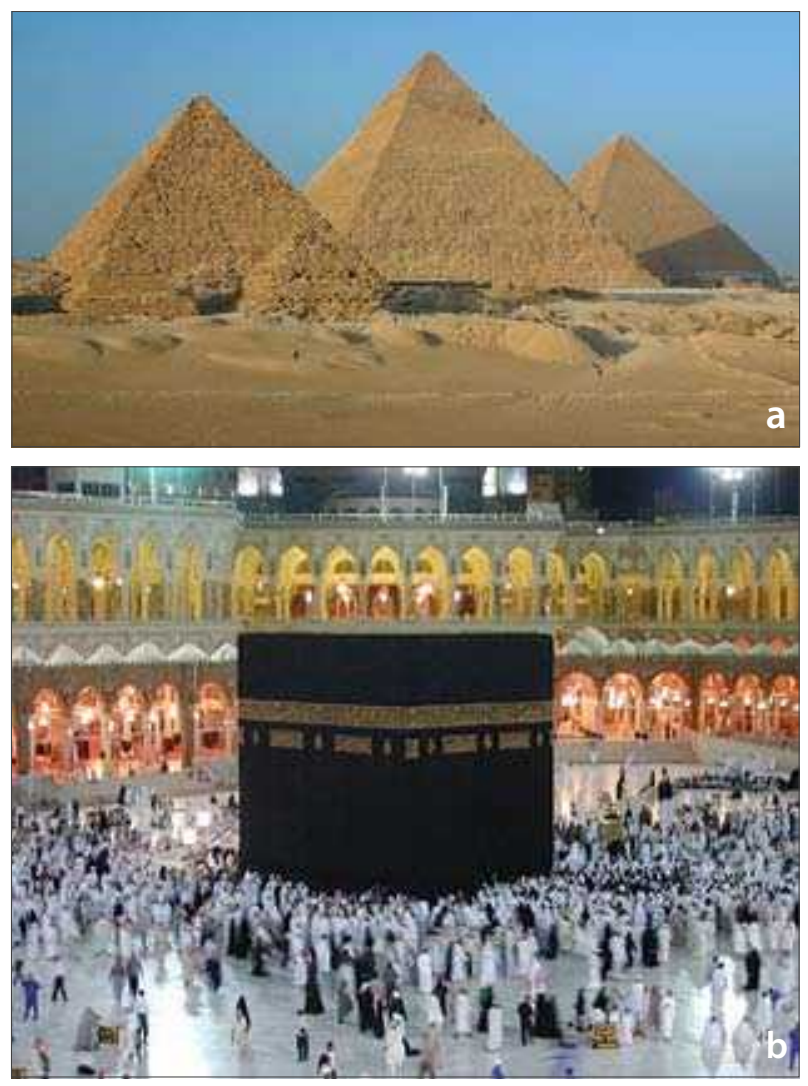

1 pav. Egipto piramidès (a); Kaaba (Meka, Saudo Arabija, 500-1000 m. po Kr.) (b)

Fig. 1. Egypt Pyramids (a); Kaaba; Mecca, Saudi Arabia, 500-1000 A.D. (b) 
nes, medžiagas, taikyti technologijas ar kitus išraiškos būdus, kitaip tariant, kokią formą tikslinga naudoti. Formos pasirinkimo klausimas kyla jau pradiniame idèjos gimimo etape: tai, ką norima išreikšti, yra labai glaudžiai susiję su tuo, kaip tą išreikšti, ir nuo to priklauso idèjos „skaitomumas“, țtikinamumas ir įtaigumas.

Architektūra - meno šaka: formavimas erdvių, tūrių, kurie be formalios vienokios ar kitokios išraiškos tiesiog neįmanomi. Net ir kituose menuose, kur nèra toks aktualus fizinis formos panaudojimas, vis tiek kūrinys yra pateikiamas vienokia ar kitokia forma, tegul kad ir konceptualizuota, prieštaringa ar sunaikinta (harmoningų dermių požiūriu).

Formos pasirinkimo problematika buvo ir yra aktuali. Nuolat yra ieškoma išraiškos būdų, naujų traktuočių, jų derinių. Šie procesai vyksta jau nuo senovès Egipto, antikos bei dar vèlesnių laikų ir ypač išryškèja $\mathrm{XX}$ a., matyt, jie bus aktualūs ir ateityje. Forma yra žmogiškojo suvokimo ir pažinimo pagrindas. Per formą yra suvokiama daiktų esmé. Ji leidžia ne tik pažinti esminius esybių ir daiktų skirtumus, bet taip pat konkrečias ir individualias jų ypatybes. Ji pati pasižymi tam tikromis savybèmis: veikia - neveikia; gali būti didelè - maža; sunki - lengva; gryna - negryna ir pan.

Formos plačiąja prasme raidai lemiamos ittakos turejo technologijų pažanga. XX a. mašininè, konvejerinè gamyba, automatizacija, elektronika sukèlè tikrą perversmą. Technologinè standartizacija paskatino formų standartizaciją daugelyje gyvenimo sričių. Formos „Švarumas“, paprastumas, struktūrinis aiškumas, kaip šiuolaikiniai estetiniai principai, yra minimalistinès raiškos, kaip logiškos kultūrinès pasekmès, pagrindas. Šiuolaikinès minimalistinès raiškos specifiką taikliai apibūdina J. Burneika: „<...> tai ir formos evoliucijos kryptis, pasižyminti formų bei priemonių santūrumu, elegantišku sterilumu, pabrèžtina visumos darna, išryškinant svarbiausią aplinkos subjektą - žmogų“. „Šis formos reiškimosi būdas, stilius labiausiai atitinka ekonomines, technologines dabartinès visuomenès galimybes“ (Burneika 2002: 21). Galima būtų išskirti formai įtakos turinčių materialių ir idealistinių veiksnių grupes (1 lentelè).

Tarp šių grupių vyksta nuolatinė trintis, kilusi dèl natūralių prieštaravimų, priklausančių nuo skirtingu epochų socialinès, ekonominès, politinès situacijos. Kaip rodo istorinè patirtis, dauguma idealių projektų nebūdavo realizuojami, o vien tik pragmatiški sprendimai atvesdavo ị aklavietę - socialiní, kultūrinị regresą. Tai verčia derinti prieštaringus veiksnius ir šis derinimas - tarsi amžinasis variklis formos evoliuci-
1 lentelè. Formos pobūdžiui turintys įtakos veiksniai Table 1. Factors determining form

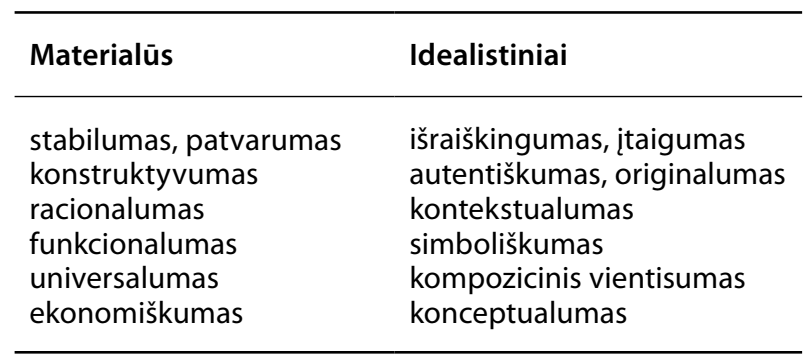

joje. Aplink mus egzistuoja didelè formų įvairovè. Tai visų pirma ịvairios gamtinès formos, kurios neabejotinai yra tobulos. Žmogiškoji formų kūryba kol kas sunkiai prilygsta gamtinei, arba dieviškajai, kūrybai, nors egzistuoja tam tikra architektūros kryptis, architektūrinè bionika, kuri analizuoja gamtines formas ir atrastus dèsningumus bando perkelti i žmogiškąsias dimensijas ir medžiagas. Tačiau tokie bandymai, kai, tarkim, gležno gèlès žiedo ar kokio kito augalo pavidalas perkeliamas ị betono konstrukciją, atrodo gana karikatūriškai. Daugelis kūrèjų tą suvokia, todèl ši architektūros kryptis nẻra itin populiari. Žmogiškoji formų kūryba nuo seno pagrịsta siekimu sukurti kiek imanoma taisyklingesnes geometrines formas, jų taisyklingumas siejamas su tobulumu. Kaip teigia J. Adomonis, geometrinių formų dėsningumai „<...> pasireiškia formos matmenyse, nusakančiuose aukštị, plotị, ilgị ir gylị. Kuo šie santykiai artimesni, tuo labiau jaučiamas formos uždarumas, statiškumas ir ramybe““ (Adomonis 1994: 113). Visuotinai yra pripažintos kaip tobulos, arba pirminès, šios geometrinès formos: kvadratas, trikampis, apskritimas, kubas, prizmè, piramidè, kūgis, cilindras, sfera. Jos yra ir abstrakčios, ir tikslios; būdamos elementarios yra tobulos, laikomos harmonijos ịsikūnijimu. Tai dèsningumai, patrauklūs akivaizdžiu aiškumu, estetiškumu. Šių pirmapradžių, be „priemaišų " formų naudojimas yra išskirtinai būdingas tradicinei minimalistinei raiškai.

Pirminėms geometrinèms figūroms taip pat yra suteikiamos simbolinès reikšmès. Ivairiuose šaltiniuose šios reikšmès nedaug skiriasi, tačiau jų esmè yra gana panaši. Pavyzdžiui, U. Becker savo Simbolių žodyne pateikia daugelio pirminių geometrinių figūrų simbolines reikšmes. Apibrěždamas apskritimą, jis rašo: „<...> Apskritimas, vienas iš dažniausiai pasitaikančių simbolinių ženklų, siejamas ar priešinamas su kvadratu. Apskritimas grịžta pats ị save, todèl yra vienovès, Absoliuto ir tobulybės simbolis, arba dvasingumo, priešingo materialumui, simbolis; glaudus ryšys jị sieja su simboline rato reikšme <...> Koncentrinis apskri- 
timas dzenbudizme simbolizuoja aukščiausią praregejjimo laipsni, visų dvasinių jègų harmoniją. Kitais atvejais, pvz., krikščionybejje, simbolizuoja įvairias dvasines hierarchijas ar skirtingas kūrimo pakopas. Trys susipynę apskritimai krikščionybëje simbolizuoja Trejybę. Kvadrate ịpieštas apskritimas - ịprastas materijoje paslèptos dieviškos ugnies kabalistinis simbolis - C. G. Jungui atrodo lyg sielos ir „aš" simbolis <... $>$ “ (Becker 1995: 21). R. Buivydas, nors ir daug glausčiau, pateikia iš esmès analogiškas apskritimo simbolines reikšmes: „Visata (Kosmas), mintis, visuminè būtis, šventumas, visa apimantis dieviškumas, tobulybè, amžinybè, oras" (Buivydas 1995: 19).

Elementarios, pirminès formos - apskritimas, kvadratas, stačiakampis, rombas, linijų ritmai, spalvų plokštumos - kiekviena, paimta atskirai, yra tarsi architektūros abėcèlè, pagrindiniai jos elementai, galintys sukelti elementarų estetinị ịspūdị. Tai ne vaizdų kalba, o apibendrinta meno, estetinių emocijų kalba, veikianti linijų, ritmų, formų, spalvos dèmių, jų derinių ịtaigumu. Ji suprantama asociatyviai. Anot H. Read, geome- trinis objektas yra „<...> paprasčiausias ir sudètingiausias menas. Paprasčiausias todèl, kad elementariausias, sudètingiausias todèl, kad abstrakčiausias" (Burneika 2002: 15). Dailès ir architektūros istorijoje egzistavo daug krypčių, kurioms buvo būdingos pirminès geometrinès formos. Tai išryškejja Senovès Egipto, antikinès Graikijos (geometrinis stilius) bei vèlesnių epochų palikime ir ypač ryšku tokiose XX a. meno kryptyse, kaip abstrakcionizmas, konstruktyvizmas, neoplasticizmas, iš kurio išsiskyrè elementarizmo pakraipa bei utilitaristinè kryptis, susijusi su Bauhauzo mokyklos principais, funkcionalizmas, racionalizmas, brutalizmas, minimalizmas. Tai rodo, kad pirminès, geometrinès formos buvo ir yra naudojamos gana plačiai ir turi skirtingą konceptualų turinị. Tačiau minimalizmo architektūroje pirminių geometrinių formų naudojimas išskirtinai ryškus, nes nè viena kryptis taip intensyviai neeksploatavo, pavyzdžiui, kad ir kubo formos grynu, pirmapradžiu geometriniu pavidalu (2 pav.).

Praeities epochose paprastos pirminès geometrinès formos dažniausiai naudojamos sakralinèje architek-
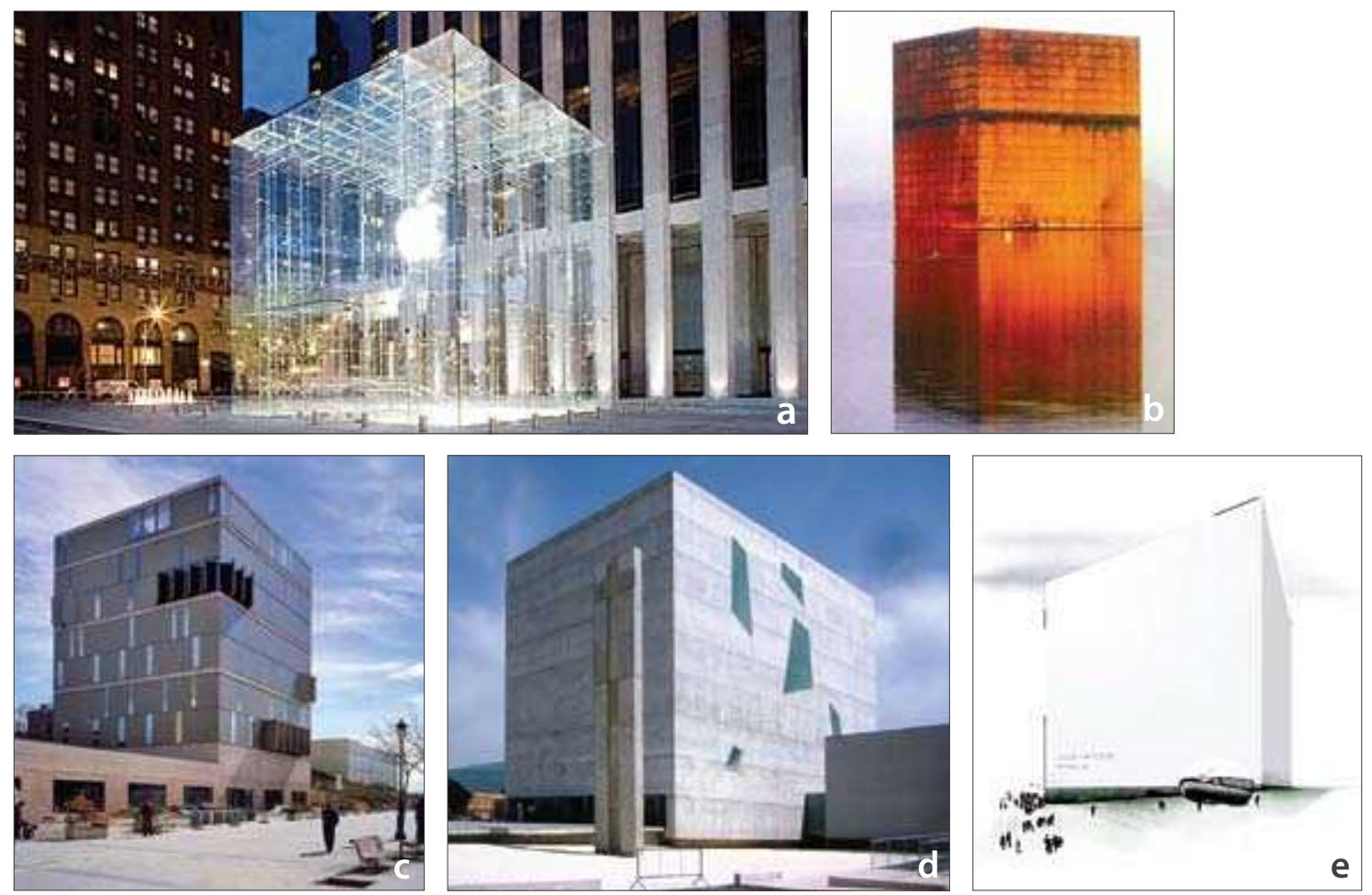

2 pav. Apple prekybos centras, Niujorkas, JAV. Archit. Bohlin Cywinski Jackson. 2007 m. (a); Expo 2002, Murten-Morat, Šveicarija. Atelier Jean Nouvel. 2002 m. (b); Usera viešoji biblioteka, Madridas, Ispanija. Arch. Abalos \& Herreros. 2005 m. (c); Bažnyčia, Folinjo, Italija. Archit. M. Fuksas. 2009 m. (d); Nacionalinis muziejus (I etapo konkursinis darbas), Oslas, Norvegija. Archit0. Urban Canvas. 2009 m. (e)

Fig. 2. Apple Store; New York; Arch. Bohlin Cywinski Jackson, 2007 (a); Expo 2002; Murten-Morat, Switzerland. Atelier Jean Nouvel, 2002 (b); Usera Public Library; Madrid, Spain; Arch. Abalos \& Herreros, 2005 (c); Church; Folinjo, Italy. Arch. M. Fuksas, 2009 (d); National Museum (I stage competition work); Oslo, Norway. Arch. Urban Canvas, 2009 (e) 
tūroje. Dabartyje matome kur kas platesnị tipologini spektrą: parodiniai, biurų pastatai, bibliotekos, bažnyčios, muziejai etc.

Pirminès geometrinès formos plačiai naudojamos ir šiuolaikiniame mene (3 pav.).

2, 3 pav. sąmoningai pateikiami pavyzdžiai, kuriuose eksploatuojama ne tik pirminè geometrija, bet būtent kubas, kaip pirminès geometrijos epogejjus, tobuliausia negamtinė forma, nors kartais jai sukurti yra panaudojamas toks gamtinis elementas kaip vanduo ledo formoje (4 pav.).
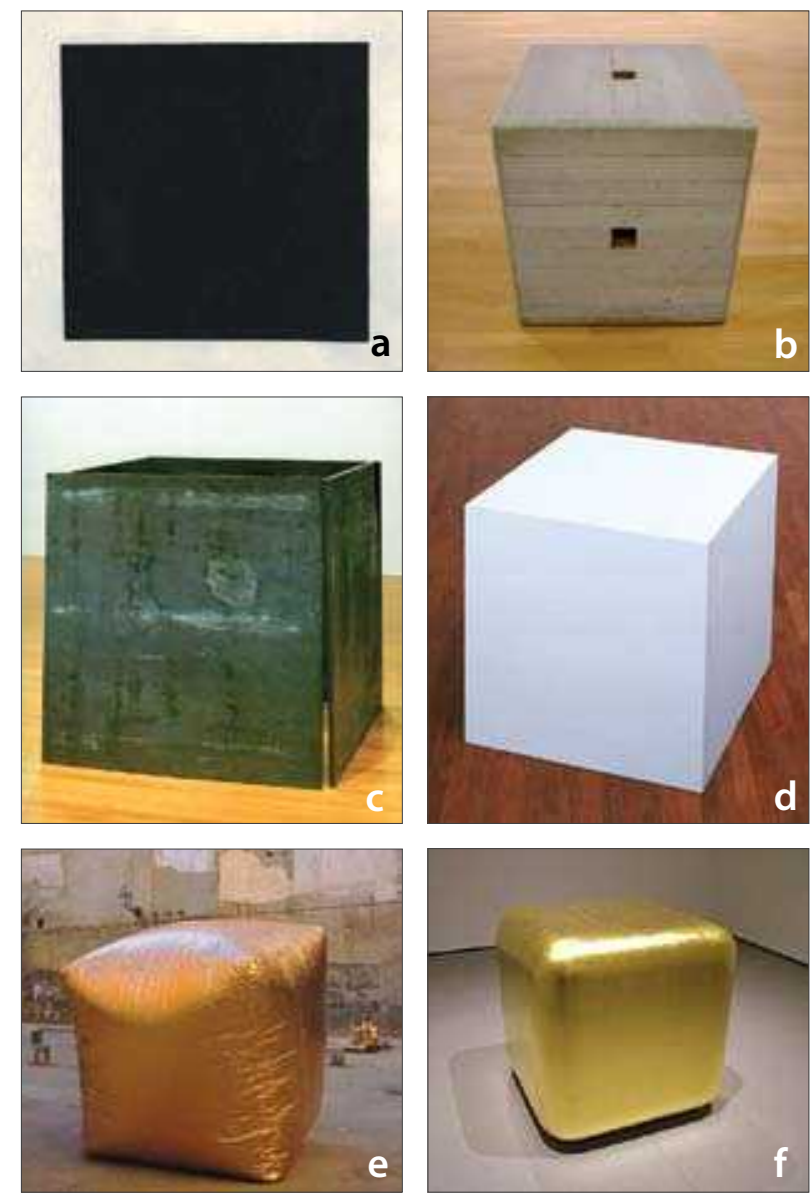

3 pav. Juodas kvadratas. Kazimir Malevich, 1913-1915 m. (a); Žalia dalis. Jackie Winsor, 1976-1977 m. (b); Vienos tonos ramsčiai (kortų namas). Richard Serra, 1969 m. (c); Be pavadinimo. Tom Friedman, 1995 m. (d); Basic House. Mobili instaliacija. Ruiz de Azua, 2000 m. (e); Tobulas stalas (auksiniai lakštai ant balto marmuro). James Lee Byars, 1989 m. (f)

Fig. 3. Black Square. Kazimir Malevich, 1913-1915 (a); Green Piece. Jackie Winsor, 1976-1977 (b); One Ton Prop (House of Cards). Richard Serra, 1969 (c); Untitled. Tom Friedman, 1995 (d); Basic House. Mobile installation. Ruiz de Azua, 2000 (e); The Table of Perfect (gold leaf on white marble). James Lee Byars, 1989 (f)

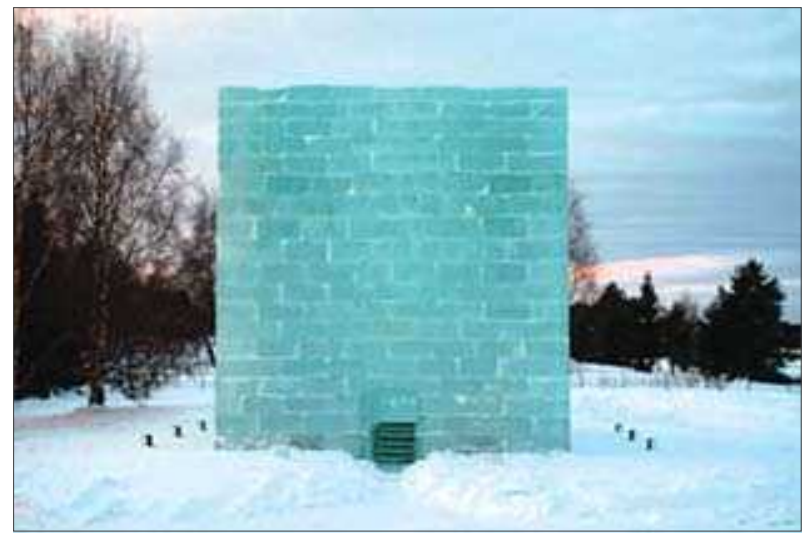

4 pav. Ledo instaliacija, Rovaniemis, Suomija. Archit. S. Holl ir J. Highstein, $2003 \mathrm{~m}$.

Fig. 4. Ice Installation; Rovaniemi, Finland. Arch. S. Holl \& J. Highstein, 2003

Tai ne visi kubo formos panaudojimo pavyzdžiai, tačiau ir iš jų akivaizdu, kad pirminių geometrinių figūrų panaudojimo spektras šiuolaikinèje architektūroje ir mene yra labai platus tipologiniu ir žanro požiūriu, taip pat turi gilias istorines šaknis.

\section{Juodojo kubo metamorfozé}

Lietuvos kontekste vienas ryškesnių kubo formos panaudojimo šiuolaikineje architektūroje atvejų administracinis Prokuratūrų pastatas ,Juodasis kubas“. 2004 m. vyko Respublikinis architektūrinių idèjų konkursas administracinio Prokuratūrų pastato vizijai nustatyti. Šiame konkurse geriausia tiek užsakovų, tiek profesionalios žiuri komisijos buvo pripažinta „Juodojo kubo" koncepcija (arch. K. Lupeikis). Konkurso sąlygose buvo nustatyta, kad privaloma neviršyti tuo metu galiojančio teritorijos detaliojo plano reglamentų, kurie numatè pastato aukštingumą iki penkių aukštų. Tačiau „Juodojo kubo“ koncepcija, siekis išlaikyti kubo formos proporcijas reikalavo aukštesnio tūrio (8-9 aukštai). Konkursiniame pasiūlyme buvo pateikta vizualinė medžiaga, kaip atrodytų 5 aukštų ir 8 aukštų tūris (5 pav.). Komisija vieningai pritare 8 aukštų tūriui, nors tai ir neatitiko sąlygų reikalavimų.

"Statybų pilotas" aptardamas ịvykusị konkursą deklaravo, kad ,juodos tiesos prokurorai nebijo“, teigiamai vertino architektūrinę išraišką: „paprastumas pabrèžia sveiką griežtumą" (Leitanaitè 2004: 6). Vystant projektą toliau teko koreguoti detalųji planą. Techninis projektas buvo parengtas $2006 \mathrm{~m}$. Konkurse deklaruota pastato koncepcija techniniame projekte buvo išlaikyta (6 pav.), nors buvo įvertinti nauji funk- 

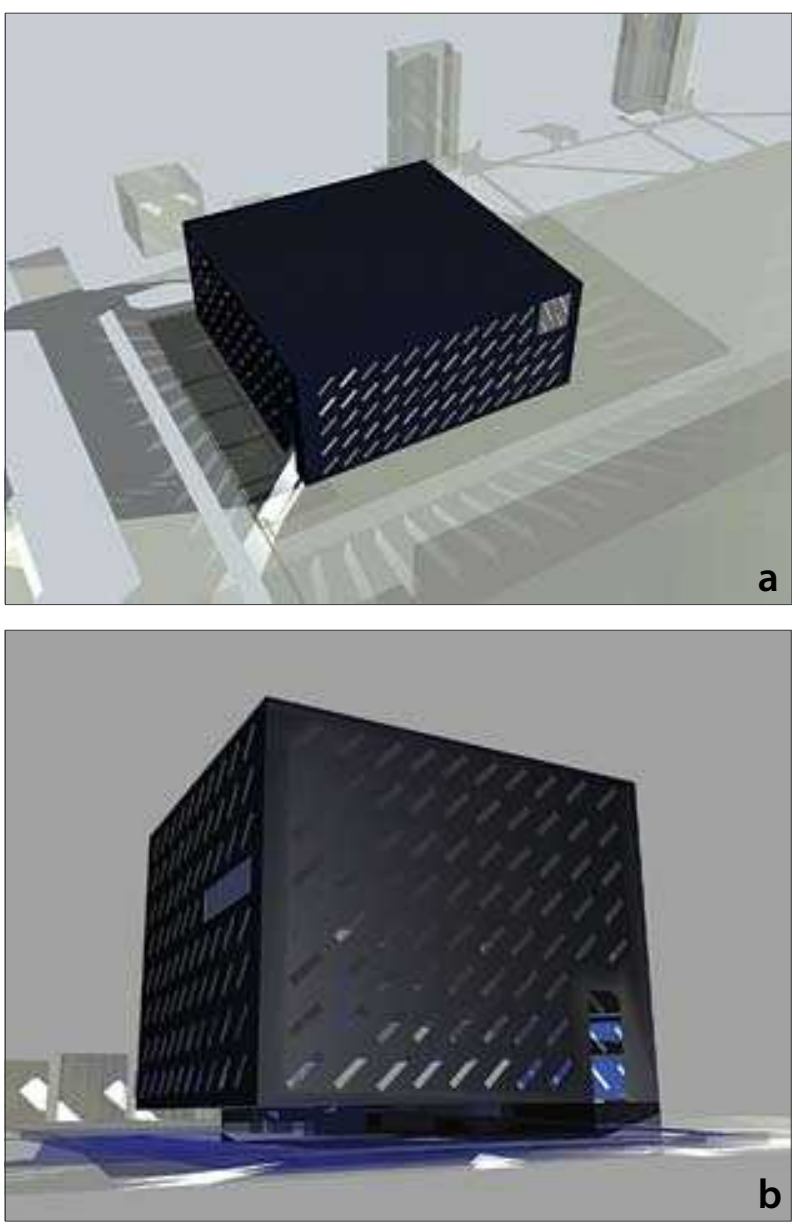

5 pav. Prokuratūrų pastatas (konkursinès vizijos) (a, b), Vilnius. Archit. K. Lupeikis, 2004 m.

Fig. 5. Prosecutor's Office Building (competition vision) (a, b), Vilnius. Arch. K. Lupeikis, 2004

ciniai, techniniai reikalavimai: „ne mažiau džiugu, kad konkursui pateikta architektūrinè koncepcija, rengiant techninị projektą, išliko net ir išsiplètus programai. 4,4 ha ploto sklype iškils masyvus juodas kubas, pakibęs virš skaidraus ịstiklinto cokolinio aukšto“, „monumentalus, skulptūriškas Prokuratūrų pastatas neabejotinai taps kvartalo dominante ir užduos toną tolimesniam kol kas anemiškos aplinkos formavimuisi“ (Leitanaitė 2006: 7).

Statybos prasidejjo 2007 m., objektas užbaigtas ir atiduotas eksploatacijai $2008 \mathrm{~m}$. pabaigoje (7 pav.). „Naujasis prokuratūrų pastatas neabejotinai tapo anemiško sostinès konteksto dominante" (Leitanaitè 2008: 4-5; 9) - rašo „Statybų pilotas“, įdėmiai stebèjęs visą projektavimo ir statybos eigą.
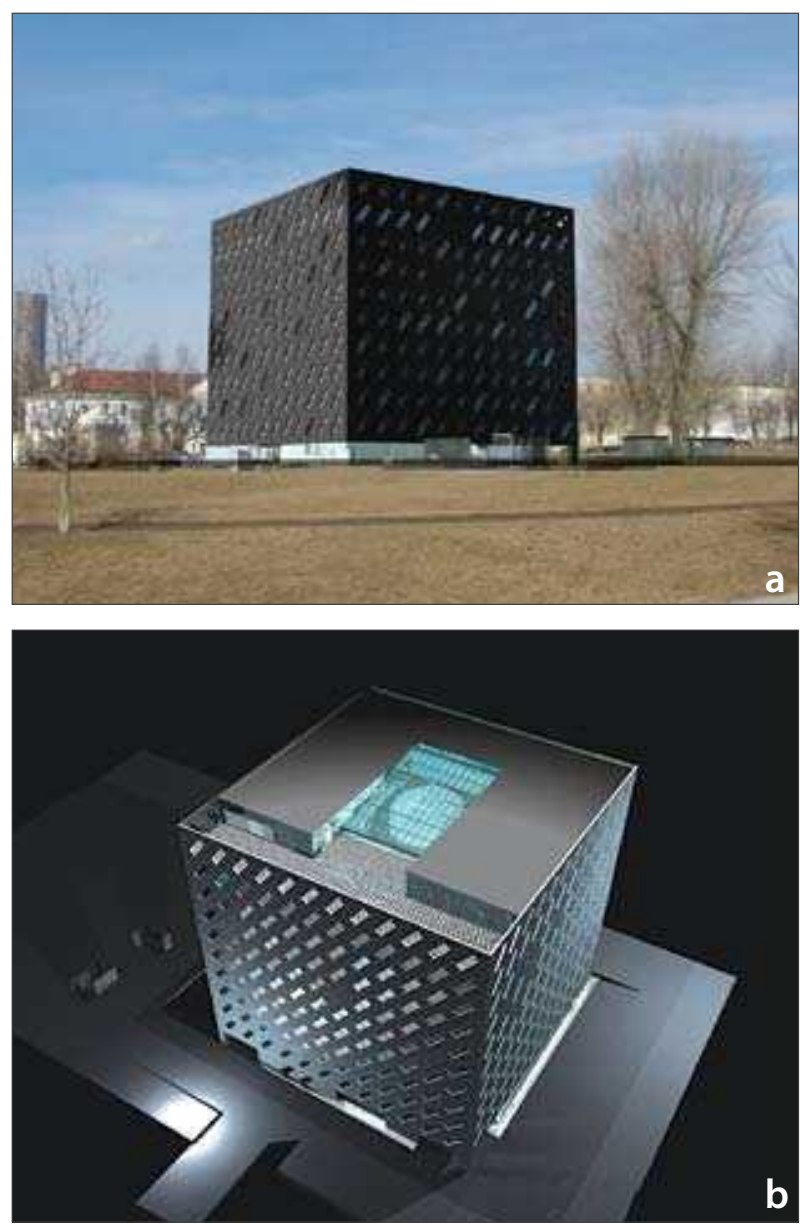

6 pav. Prokuratūru pastatas (TP vizualizacijos) (a, b), Vilnius. Archit. K. Lupeikis, 2006 m.

Fig. 6. Prosecutor's Office Building (TP visualizations) (a, b), Vilnius. Arch. K. Lupeikis, 2006

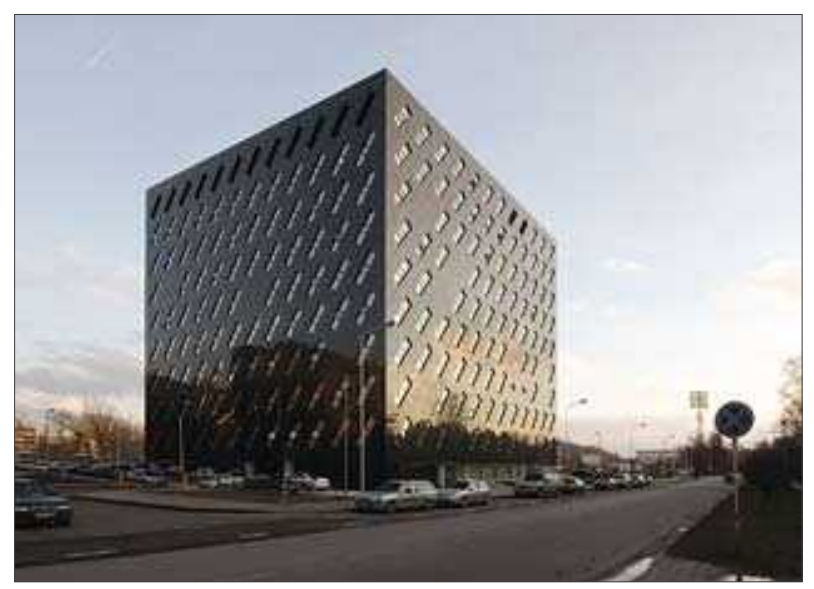

7 pav. Prokuratūrų pastatas, Vilnius. Archit. K. Lupeikis, $2008 \mathrm{~m}$.

Fig. 7. Prosecutor's Office Building, Vilnius.

Arch. K. Lupeikis, 2008 


\section{Prieštaringi vertinimai}

"Juodojo kubo“ atsiradimas Vilniuje buvo pastebètas ir Lietuvoje, ir užsienyje. Jau 2006 m. liepos mènesi atidaryta atskira skiltis internetiniame tinklalapyje www.miestai.net, kur iki dabar (2009 m. rugsejo mèn.) pateikiamos objekto projekto ir statybos nuotraukos, ìvairios necenzūruojamos nuomonès. Šiame tinklalapyje taip pat buvo atliekamas balsavimas vertinant balais (2 lentelè).

2 lentelè. Prokuratūru pastato vertinimas balais $2008 \mathrm{~m}$. Table 2. Prosecutor's Office Building evaluation

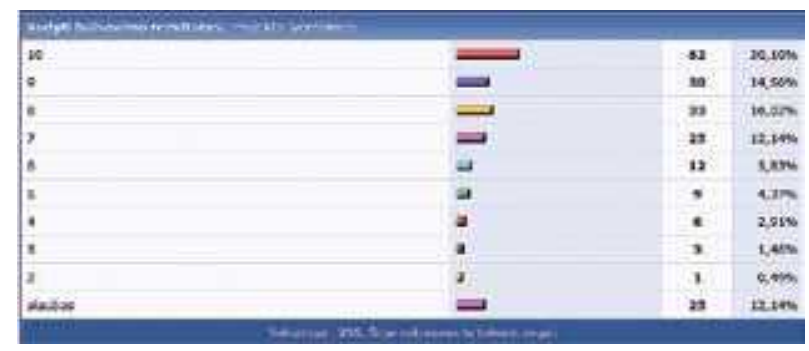

Ypač daug dèmesio jam buvo skirta 2008 m., statybos pabaigoje, kai realiai pradejo matytis rezultatas. Lietuvoje Prokuratūru pastatas buvo ivertintas $2007 \mathrm{~m}$. kaip geriausias parodos „Vilniaus architektūra 20052006" projektas, o 2009 m. pradžioje jam buvo įteikta "Archiformos" architektūrinè premija už geriausią $2008 \mathrm{~m}$. realizaciją, taip pat 2009 m. parodos „Vilniaus architektūra 2007-2008“ metu visuomenès balsais pelnè I vietą už geriausią realizaciją. „Netradicinès meninès raiškos formos visuomet sulaukia atgarsio. Tai galima pasakyti apie sostinèje iškilusị naują neịprastos formos administracinị Prokuratūrų pastatą. Projekto autoriui, architektui Kęstučiui Lupeikiui drąsiomis ir nekasdieniškomis architektūros idejomis pavyko sukelti diskusiją visuomeneje nuo pat projekto igyvendinimo pradžios. Architektas K. Lupeikis, pasirinkęs minimalias išraiškos priemones, sukūrè vieną iš moderniausių ístaigos pastatų. Projekte atsisake pastatams iprastų geometrinių formų ir pasirinko tarsi baigtinę kubo formą, siekdamas architektūrinio aiškumo ir paprastumo. Virš skaidraus ịstiklinto cokolinio aukšto iškilęs masyvus juodas kubas išraiškingai pabrèžia stabilų, tvirtą, lyg uola nepajudinamą teisèsaugos institucijos įvaizdį“. Taip apie „Juodąji kubą“ rašè 2008 m. pabaigoje periodinis leidinys „Statyba ir architektūra" (Levandraitytè 2008: 27). Beveik tuo pat metu J. Kšivickaitè „Archiformoje“ nagrinejja Prokuratūrų pastato formos ypatybes: „Pasirinkta pastato forma iš esmès nèra originali. Apie kubą, kaip pirminę geometrinę formą, kalbejjo jau Platonas“. „<...> autorius netiesiogiai patvirtina chrestomatini pastato funkcijos ir formos santyki. Tačiau tai nèra formalus formos atspindys išorèje, veikiau konceptualus pasirinkimas" (Kšivickaitè 2008: 41). Tam pritaria ir „Nauja statyba“: „Taisyklinga pastato forma - kubas - yra vienas svarbiausių šio projekto idèjos sprendimų “ (Štelbienè 2009: 22). „Veidas" pristatydamas Prokuratūrų pastatą teigia, kad „,_..> architekto vaizduotèje „apsigyveno“ griežta, tvarkinga, koncentruota statinio forma. Ir juoda teisingumo mantijos spalva. Ne matinè, $o$ atspindinti. $\mathrm{Ne}$ iš stiklo ar plastiko, bet iš solidžiai švytinčio šlifuoto juodo granito“ (Baltrušaitytė 2009: 50). „Vyrai juodais drabužiais. Tokia mintis šauna ị galvą apie naujo - futuristinio griežtos kubo formos juodo pastato ịstrižais langais darbuotojus. Ir tai beveik tiesa. Kubas - nauja prokurorų būstinè Vilniuje. <...> pastatas vertinamas labai prieštaringai“ - rašo „Lietuvos ryto priedas“ „Būstas“ (Jarmalis 2008: 8). Labai taikliai plačiosios visuomenès abejones dèl šio pastato apibūdina „Namas ir aš“: „Kęstučio Lupeikio suprojektuotas administracinis prokuratūros devynaukštis šiandien tikrai yra labiausiai aptarinèjamas Vilniaus pastatas. Tarp daugybès senų ir naujų Vilniaus pastatų prokuratūra išsiskiria savo juodu paviršiumi, nusėtu ịstrižomis langų angomis. Būtent apvalkale kritikai bando įžvelgti pastato simbolines reikšmes, o gal net ir patys jas susikurti. Žmonių mintyse paviršiaus modeliuojami ženklai pačius stebètojus žavi, glumina arba piktina. Vieni čia ižvelgia modernumą ir minimalizmą, t. y. grynumą, kurio taip trūksta Vilniaus architektūrai. Kitus stebina netikèta, dèmesị kaustanti langų kryptis, kuri siejama su ekscentrišku požiūriu i konservatyvią prokuratūros funkciją. Trečius juodas kiautas su ambrazūromis piktina, nes Lietuvos teisèsaugai suteikia paslaptingo atgrasaus uždarumo įvaizdị“ (Truskauskienė 2009: 71).

Kai kurie kolegos architektai, pripažindami „Juodojo kubo" paveikumą, abejoja dèl jo santykio su aplinka, priekaištauja dèl kontekstualumo stokos: „Šio projekto igyvendinimas iš esmès pakeite vietos veidą. Žaviuosi taupia ir paprasta architektūros kalba. Tačiau pasakyti taupiai, vartojant minimalią architektūrinę kalbą, yra viena. Pasigendu draugiškumo, neabejingo santykio su aplinka“. Savo nuomonę „Statybos ir architektūros" korespondentei toliau dèstė architektas Rolandas Palekas: „<...> ,juodasis kubas“ tarsi išreiškia 
norą ignoruoti savo aplinką". R. Palekas šiuo atveju tai laiko trūkumu. Jis pažymèjo, kad „kubas yra labai ịsimintinas, lakoniškas ir pastebimas, todèl abejingų šiam projektui tikrai neliks. Tačiau vieni pastatu džiaugsis, kiti bus nusiteikę priešiškai. Manau, kad architektui K. Lupeikiui pavyko išprovokuoti nevienareikšmi jo kūrinio vertinimą. Gerbiu ji už tai, kad turi tvirtą požiūrị i architektūrą ir jos santykị su aplinka, kad nebijo apie tai garsiai pareikšti“, - savo mintis dèstè R. Palekas. Kaip teigiamą aspektą Lietuvos architektų sąjungos pirmininkas Gintautas Blažiūnas išskiria, kad „K. Lupeikio projektas nesusilies su miestu ir "užduos“ teritorijai naują tonaciją“. O architektas Gintaras Čaikauskas pažymëjo, kad tai vietai „užduotas tonas“ prašosi užbaigiamas. „Kubas yra savarankiška forma, bus nelengva kažką prie jos pritaikyti. Ji iškelia kompozicinių problemų, reikalauja itin aukšto meistriškumo, o kartais šalia savęs nenori priimti nieko" (Levandraitytė 2008: 31).

Viešojoje erdveje pasitaike ir kur kas aštresnių nuomonių apie „Juodąji kubą" ir jo autorių. Štai filosofijos mokslų daktaras, kultūrologas Vytautas Rubavičius internetiniame tinklapyje www.balsas.lt publikuoja savo mintis: „<...> jei reikètų rinkti labiausiai Lietuvos urbanistinę terpę užteršusį architektą, <...> drịstu manyti, kad ị konkurso laureatus pretenduotų architekto Kęstučio Lupeikio statinys - Administracinis prokuratūrų pastatas Vilniuje, Rinktinès gatvejje. To pastato neimmanoma nepastebėti. Juodas kubas, nudygsniuotas ¡kypomis ambrazūromis. Kupinas prašalaičiams neprieinamo paslaptingumo, atgrasaus uždarumo - net langais nesisieja su išoriniu pasauliu, kadangi jų šviesos nepakaktų vidiniam gyvenimui. Paslaptingumas agresyvus, nes neprisileidžia jokių žmogiškų jausmų. Agresyvus ir statinio demonstratyvus atsiribojimas nuo aplinkos, įstrižų ambrazūrų ironija Gedimino bokšto tiesių ambrazūrų atžvilgiu. Bokštas kyla aukštyn, jis teigia vertikalią žmogaus gyvenamo pasaulio dimensiją, o kubas sąmoningai neigia vertybinès krypties išskirtinumą, atmeta vertybinę orientaciją. Statinys minimalistinès architektūros pavyzdys. Tokia architektūra - konceptuali. Ji nèra prasminga, tačiau visada kreipia ị vienokias ar kitokias esmes, nes atsiribojantis bei atribojantis konceptualumas - iškalbingas. Ką byloja, ką nurodo šis neprasmingas, tačiau iškalbingas statinys? Jis akivaizdžiai teigia neperžengiamą prarają, skiriančią teisèsaugą ir visuomenę... Galètume sakyti taip: piliečiui neprieinamas teisingumas egzistuoja socialiniame kūne atsiradusioje juodojoje skylèje... Architektūrinis minimalistinès architektūros totalitarizmas šiuo atžvilgiu atitinka korupcinio teisingumo totalitarizmą. Statinys lygiai taip nesileidžia ị jokias kalbas su aplinka, kaip kad teisèsaugai net neateina i galvą mintis kalbètis su visuomene... Vakarietiškos demokratijos šalyse tokio pobūdžio statinys sukeltų didelị visuomenès atsaką..." (Rubavičius 200902 10).

Iš tikrųjų Prokuratūrų pastatas rezonavo ir Vakaruose, tik, kiek žinoma šio straipsnio autoriui, reakcija buvo pozityvi, o ne kaip V. Rubavičius prognozavo - negatyvi. Matyt, „Juodajam kubui“ būti pastebėtam užsienyje padèjo dalyvavimas prestižiniame Mies van der Rohe Europos sąjungos apdovanojimo $2009 \mathrm{~m}$. konkurse, kur jis buvo nominuotas kartu su kitais 5 Lietuvos architektų sąjungos komisijos deleguotais objektais. „Juodojo kubo“ pristatymą publikavo kaimyninès Lenkijos internetinis laikraštis www.bryla. gazetadom.pl ir Vasario 16-osios proga Latvijos internetinis tinklalapis www.a4d.lv: „Pasirinkęs minimalistę išraišką, architektas sukūrè vieną iš moderniausių visuomeninių pastatų Lietuvoje" (Zvirgzdiṇš 200902 16). Prokuratūrų pastato koncepcija pristatoma ir kituose užsienio internetiniuose tinklalapiuose: www. miesarch.com; www.urbarama.com; www.flickr.com; www.e-architect.co.uk; www.arquinauta.com; www. a10.eu; www.archires.documentation.equipement. gouv.fr; www.ktpmalta.com; www.forgemind.net; www.issuu.com. Nuomonės apie „Juodąji kubą“ buvo publikuotos profesinèje užsienio periodikoje: Baltijos jūros regiono leidinyje project baltia 09/02; olandų A10/ new European architecture 2009\#26; šveicarų prestižiniame leidinyje Modulor 2009\#3. Pastarajame menotyrininkas Patrick Zamarian rašo: „Dèmesio verta ne tik formos kalba, bet ir dvasinè laikysena, dèl kurios pastatas tampa labai išraiškingas" (Zamarian 2009: 68).

Priešingų nuomonių "Juodojo kubo" kritikams netrūksta ir Lietuvoje. E. Truskauskienė rašo: „Man patinka prokuratūros pastato drabužis. Visų pirma dèl drąsios idèjos, kuria architektas sugebèjo uždegti Lietuvos teisèsaugą. Taip pat dèl neabejotinos pedagoginès reikšmès. Tai akivaizdus įrodymas kitiems esamiems ir būsimiems architektams, jog nei konservatyvi funkcija, nei ribotos lèšos nẻra tos priežastys, kurios gali užkirsti kelią kūrybinei laisvei.

Drịsčiau teigti, kad Kęstučio Lupeikio kūrinys visiškai atitinka laiko dvasią ir atstovauja vienai iš pirmaujančių pasaulio architektūrinių tendencijų - skinarchitecture, kuri žavi savo techniškumu ir interaktyvumu" (Truskauskienè 2009: 73). 


\section{Juodojo kubo „kūnas“}

SKLYPAS yra centrinëje Vilniaus dalyje apie $1 \mathrm{~km}$ nuo istorinio miesto centro. Tai naujojo administracinio centro ašies, lygiagrečios Neries upei, tąsa (8 pav.).

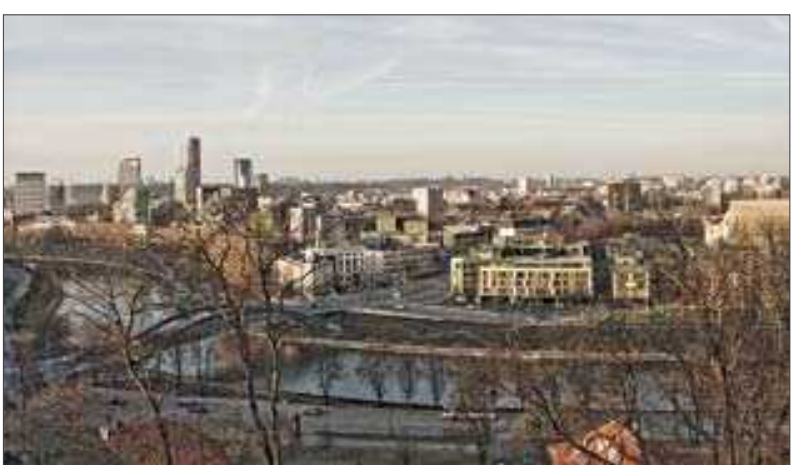

8 pav. Vaizdas nuo Gedimino kalno, 2008 m.

Fig. 8. View from Gediminas Hill, 2008

Ši teritorija iki šiol nebuvo urbanistiškai išvystyta, nors čia nuo seno koncentruojasi prokuratūros ịstaigos. Foną naujam Prokuratūrų pastatui sudaro toliau esantys 9 aukštų daugiabučiai gyvenamieji namai. Projektuojamas pastatas statomas sklype arčiau prie Rinktinès gatvès, išlaikant gatvès užstatymo liniją (9 pav.). Sklypas užima $4433 \mathrm{~m}^{2}$, užstatomos teritorijos plotas $-1505,25 \mathrm{~m}^{2}$.

Esamas reljefas neturi didelių aukščių skirtumų. Ivažiavimas, keliai, automobilių stovèjimo aikštelè, pèsčiųjų takai sklandžiai ịsilieja ị esamą reljefą. İvažiavimas ị sklypą sprendžiamas, rekonstruojant

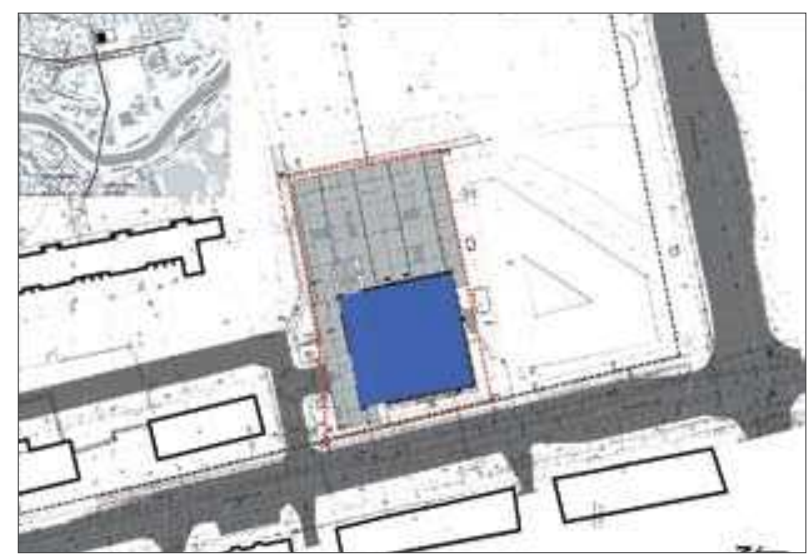

9 pav. Prokuratūrụ pastatas (generalinis planas), Vilnius. Archit. K. Lupeikis, $2006 \mathrm{~m}$.

Fig 9. Prosecutor's Office Building (General Plan), Vilnius. Arch. K. Lupeikis, 2006 esamą ịvažiavimą i esamą prokuratūrą. Išplatinama Rinktinès gatvè, įrengiant lètėjimo ir greitėjimo juostas. Rekonstruojamas pèsčiųjų šaligatvis prie Rinktinès gatvès ir aplinkiniai pèsčiųjų takai. Prie pastato, sklypo teritorijoje projektuojama autonomiška 62 vietų automobilių stovèjimo aikštelè, kurioje numatomos 5 vietos ŽFT (žmonès, turintys fizinių trūkumų) automobiliams (10 pav.).

Pèsčiujų takai suprojektuoti taip, kad sklandžiai, be laiptų ịsilietų ị esamą šaligatvinių takų tinklą. Likusioje teritorijos dalyje pasodinama veja, dekoratyviniai medžiai ir krūmai. Projektuojant teritorijos paviršių buvo siekiama maksimaliai prisitaikyti prie esamų aukščių ir išlaikyti esamo paviršiaus pobūdị (11 pav.).

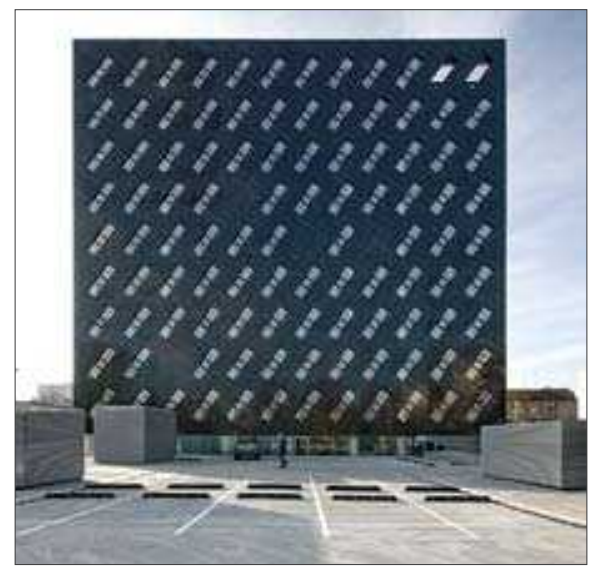

10 pav. Prokuratūru pastatas (rytų vaizdas), Vilnius. Archit. K. Lupeikis, 2008 m.

Fig. 10. Presecutor's Office Building (south view), Vilnius. Arch. K. Lupeikis, 2008

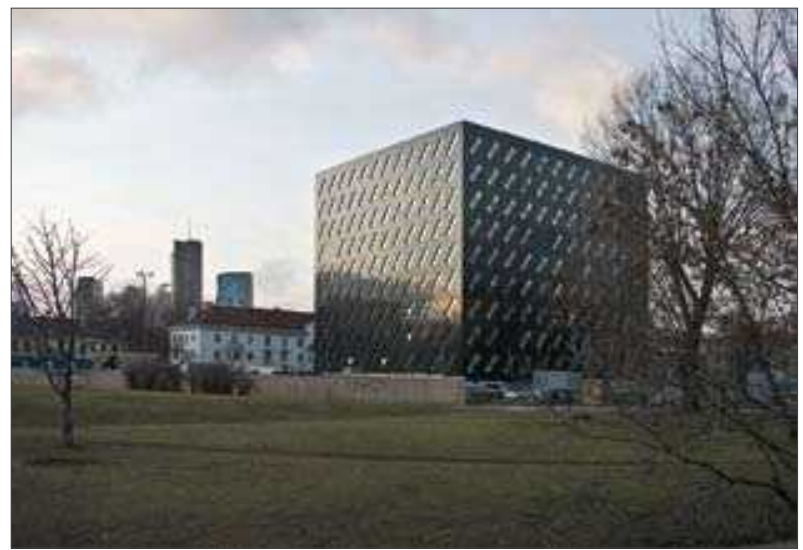

11 pav. Prokuratūru pastatas (pietryčių vaizdas), Vilnius. Archit. K. Lupeikis, $2008 \mathrm{~m}$.

Fig. 11. Prosecutor's Office Building (south-east view), Vilnius. Arch. K. Lupeikis, 2008 
STRUKTŪRA ir FUNKCIJA. Administracinis Prokuratūrų pastatas yra 13 aukštų: 9 antžeminiai, 3 požeminiai ir cokolinis aukštas. Statinio aukštis nuo žemès paviršiaus $-35 \mathrm{~m}$. Bendras plotas $\sim 17500 \mathrm{~m}^{2}$, antžeminès dalies bendras plotas $\sim 9200 \mathrm{~m}^{2}$.

Projektuojamo objekto apimtis ir struktūrinis sprendimas - pagal užsakovo reikalavimus.

Požeminiuose aukštuose įrengtos techninès, archyvų patalpos, automobilių stovèjimo aikštelès.

I pastatą patenkama per cokoliniame aukšte esančius įejjimus. Visas cokolinis aukštas įstiklintas, užlietas šviesos. Jame įrengtos priemimo patalpos, apsaugos postai, personalo kabinetai, patalpa žiniasklaidos atstovams ir kavinè.

Kompaktiško tūrio nulemta planinè struktūra - paprasta. Universalumo, racionalaus funkcinių poreikių tenkinimo siekiama formuojant lanksčią struktūrą, kurią, reikalui esant, galima transformuoti (12 pav.).

Nuo cokolinio pastato aukšto atsiveria tuščia vidinè erdvé - atrijus su „kabančiomis“ konferencijų bei posédžių salèmis. Jis atlieka rekreacinę funkciją, suformuoja savitą pastato vidinį kiemą, šerdị ir kyla aukštyn iki
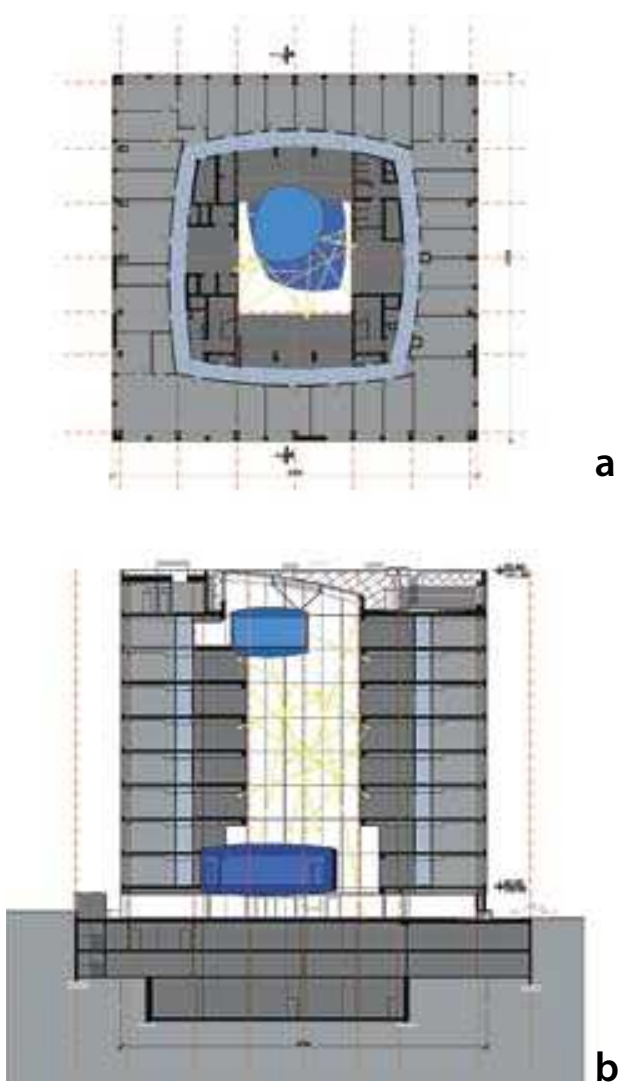

12 pav. Prokuratūru pastatas: tipinis aukšto planas (a); pjūvis (b), Vilnius. Archit. K. Lupeikis, 2006 m.

Fig. 12. Prosecutor's Office Building: typical floor plan (a); section (b), Vilnius. Arch. K. Lupeikis, 2008 pastato viršuje įrengto stoglangio. Visi pastato aukštai susiję su šia šviesos pilna erdve. Kartu juos jungia bendros erdvės, poilsio patalpos, liftų holai (13 pav.).

Atrijaus akcentai - „kabančios“ salès. Tai - lyg pastato „širdis“ ir „smegenys“. Salių forma - transformuoti pirminiai geometriniai tūriai su dvigubo kreivumo kupolais ị viršų ir apačią, „pakabinti“ trapioje, atspindžių nutviekstoje atrijaus erdvèje. Apatinè 150 vietų konferencijų salè yra pirmame pastato aukšte ir su savo žemai pakibusiu kupolu atrodo tuoj prislègs tik ièjus ị pastatą (14 pav.).

Viršutinė vadovybės posėdžių salè „pakibo“ aukštybèse - aštuntame aukšte - ir stebi viską matančia akimi (15 pav.).

Suprantama, salès pakibusios sąlygiškai. Jos iš dalies patenka ị atrijų, sudarydamos ịspūdị, kad yra vizualiai pakibusios ore. Pirmojo aukšto salè atsiremia ị kolonas ir kabo tik iš dalies. Antroji - ties aštuntu aukštu „pakabinta“ ant metalinių konstrukcijų. Devintajame aukšte įrengtas prokuratūros personalo

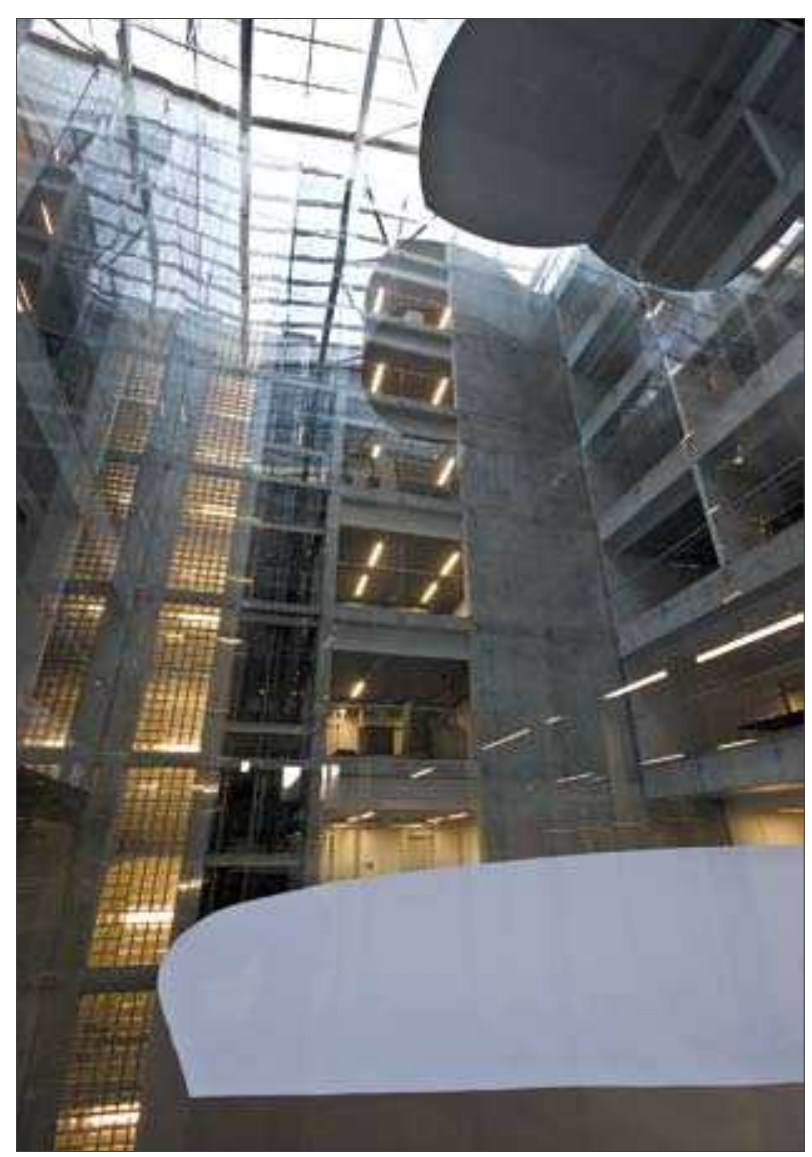

13 pav. Prokuratūru pastato atrijus, Vilnius. Archit. K. Lupeikis, $2008 \mathrm{~m}$.

Fig. 13. Prosecutor's Office atrium, Vilnius. Arch. K. Lupeikis, 2008 


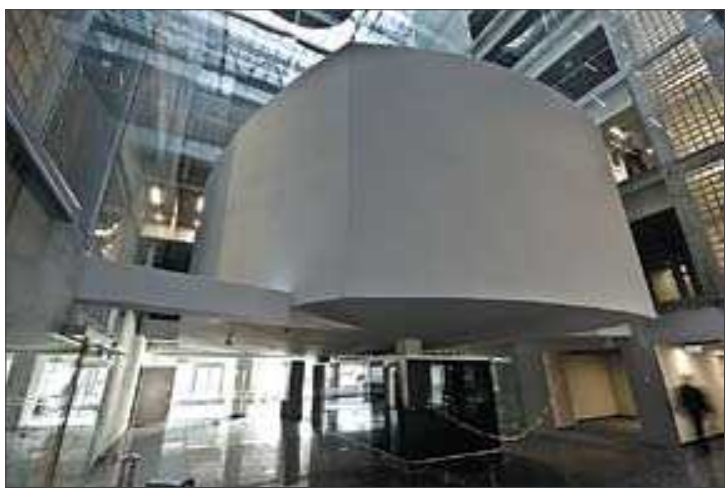

14 pav. Prokuratūrų pastato konferencijų salè, Vilnius. Archit. K. Lupeikis, 2008 m.

Fig. 14. Prosecutor's Office Building conference hall, Vilnius. Arch. K. Lupeikis, 2008.

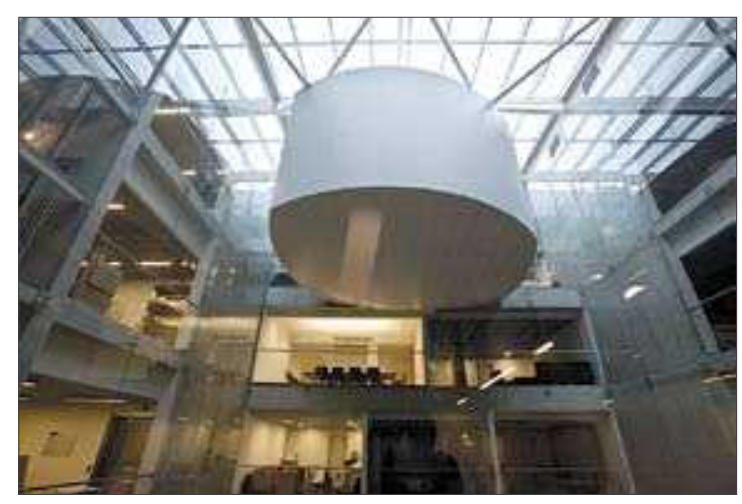

15 pav. Prokuratūrų pastato vadovybės posėdžių salè, Vilnius. Archit. K. Lupeikis, 2008 m.

Fig. 15. Prosecutor's Office Building administration meeting-hall, Vilnius. Arch. K. Lupeikis, 2008.

mokymo centras su dar viena, tik jau stacionaria sale. Iš viso įrengti 292 kabinetai, kuriuose dirbs daugiau nei 375 žmonès.

MEDŽIAGOS ir APDAILA. Objekte buvo siekiama naudoti natūralias medžiagas: akmenį, betoną, medị, stiklą, metalą etc. Vidaus apdailai naudojamos paprastos, lengvai eksploatuojamos, užtikrinančios gerą estetinị interjerų lygị medžiagos: grindys - homogeninis linoleumas, keraminès plytelès, granito plokštės, parketas, kilimine danga; sienos, kolonos, sijos - gipso kartono plokštės (glaistytos, dažytos), sienos virtuvėse ir sanitariniuose mazguose - keraminès plytelès; pakabinamos lubos - gipso kartono plokštès (glaistytos, dažytos), ažūrinès metalinès grotelès.

Atrijaus apdaila - betonas, dažytas skaidriais lateksiniais dažais, padengtas skaidriu beremiu stiklu.
„Kabančių“ salių apdaila - gipso kartono plokštès (glaistytos, dažytos).

Lauko sienų ir angokraščių apdailai naudojamas juodas poliruotas granitas (16 pav.), devinto aukšto lauko sienoms, išeinančioms į terasą, - minerito plokštė (gruntuota, dažyta), plokštuma virš pagrindinio įejimo - tinkas. Langų rèmai - aliumininiai, juodi. Stoglangio rèmų spalva pilka. Cokolinio aukšto vitrinos - aliuminio rèmai, įleisti ị vidų. Atraminių sienučių aplink pastatą apdaila - akmens masès plytelès.
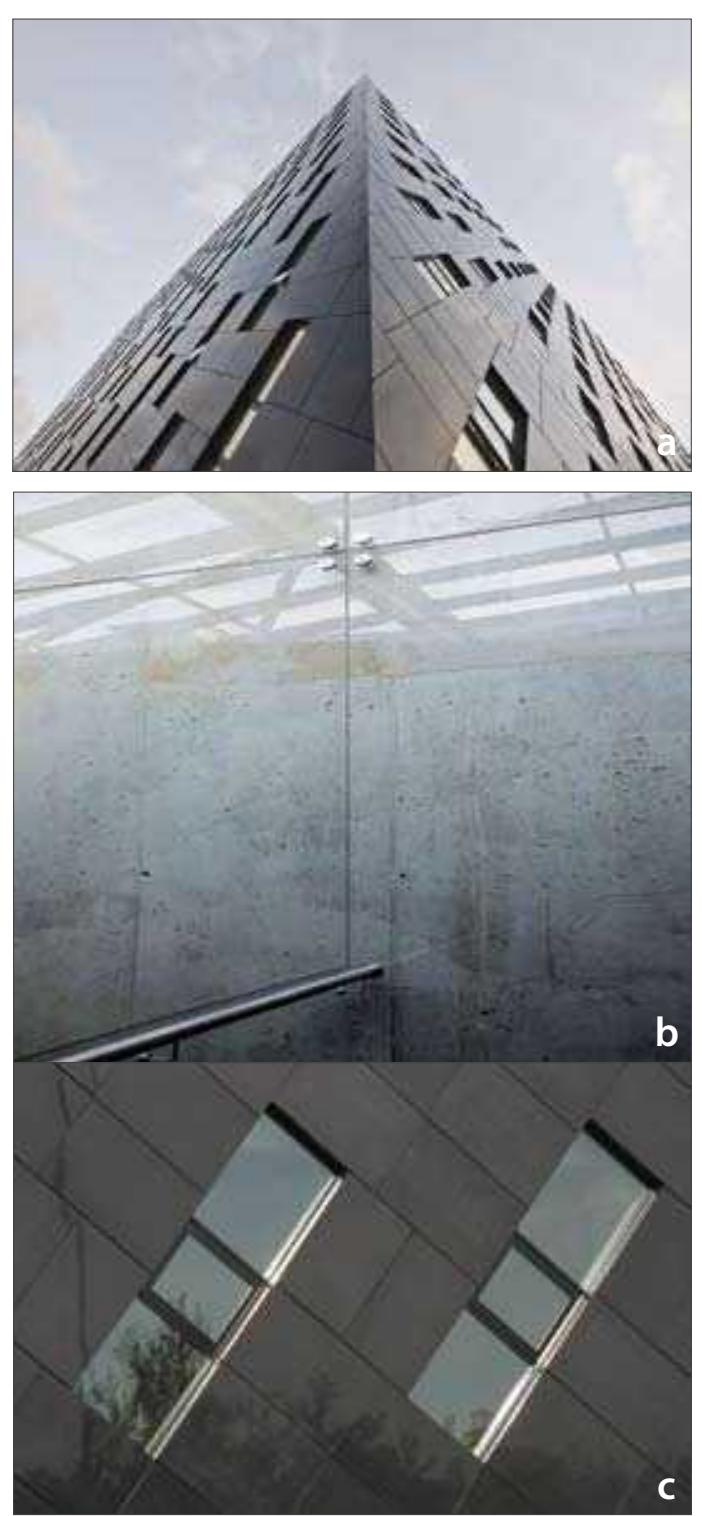

16 pav. Prokuratūrų pastato detalès $(a, b, c)$, Vilnius. Archit. K. Lupeikis, $2008 \mathrm{~m}$.

Fig. 16. Prosecutor's Building details ( $a, b, c)$, Vilnius. Arch. K. Lupeikis, 2008. 
SPALVA ir ŠVIESA. Minimalistineje architektūroje spalva - ne puošmena, bet formos kalba. Maggie Toy apie minimalistinę spalvų gamą rašo: „<...> spalvinès schemos pagrindas dažniausiai yra baltos spalvos variacijos, kurios leidžia atsispindèti aplinkinèms spalvoms ir šviesai atsispindèti erdvèje <...>" (Maggie 1996: 7). Architektūroje kiekvienas elementas yra spalvotas, ir spalvų derinimas vadinamas pastato spalvine kompozicija. Spalva galima pabrèžti geometrinès formos konstrukcinę esmę, architektoniką. Kartais spalva gali radikaliai pakeisti architektūrinès formos vaizdą, jos erdvinę bei plastinę išraišką ir prasminị turinị. Taigi spalva galima niveliuoti arba paryškinti formą ir ją aktyviai keisti, spalvos atveria platų emocinio poveikio diapazoną.

Tradiciškai minimalizmas liudija objekto savarankiškumą, absoliutų geometrinį formos ir erdvès grynumą, visiškai vienarūšius, vienspalvius (monochromatinius) paviršius - dažnai visiškai arba beveik baltus. Prokuratūrų pastato atveju - eksterjere dominuoja juoda spalva. Ir tai nèra vienintelis atvejis minimalistineje architektūroje (17 pav.).

Šviesa,$-<\ldots>$ visur esantis reiškinys, žinomas mums savo poveikiu, bet jo esmè toli gražu nesuvo-
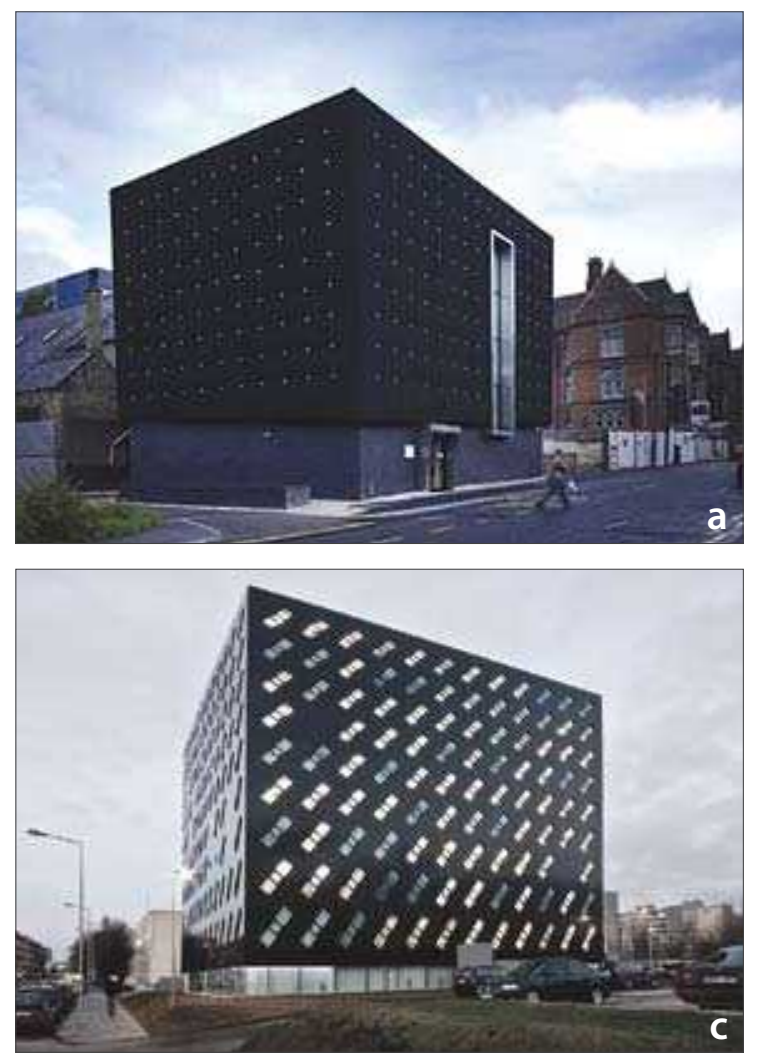

kiama. Todèl jis simboliškai laikomas nematerialumo, sielos, dieviškojo prado, gyvenimo, laimès atitikmeniu“" (Becker 1995: 274). Šviesa architektūroje ir ypač minimalistinèje yra dažnai naudojama išraiškos priemonè. Tai ne tik apšvietimo šaltinis, o greičiau veiksnys, sukuriantis specialią meditacinę, metafizinę raišką, kompozicinè priemonè, išryškinanti tekstūras, faktūras, ažūrinius, permatomus darinius, formą.

Šviesą minimalistai laiko vienu iš svarbiausių erdvès, tūrio ir spalvos modeliavimo bei formavimo elementų. Realiai egzistuojančių architektūros erdvių ir formų plastika nepajuntama be šviesos. Šviesa išryškina formos apimtį, reljefiškumą. Labai svarbu, kokiu metų ar dienos laiku bus labiausiai išryškintos jos formos, koks bus šešèlių ir atspindžių gilumas (18 pav.).

Apšvietimas yra svarbus meniniu bei emociniu požiūriu. Šviesa iliuziškai lyg palengvina pastato svorị, suteikia jam ažūriškumo (19 pav.).

KONSTRUKCIJOS ir INŽINERIJA. Objekto konstrukcinę sistemą sudaro monolitinio gelžbetonio poliniai pamatai, kolonos, branduoliai ir perdangos. Antžeminèje dalyje laikanti sistema - metalinių kolonų ir sijų struktūra per visą pastato perimetrą su centriniais monolitinio gelžbetonio branduoliais ir perdan-

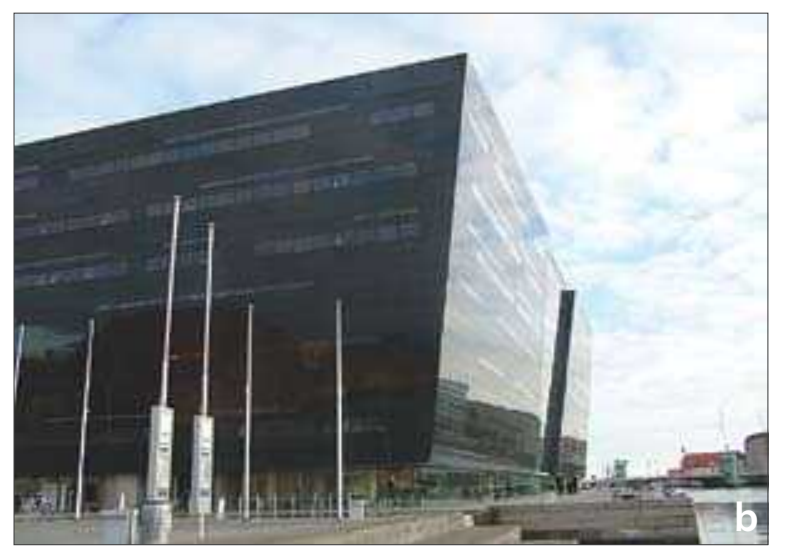

17 pav. SoundHouse, Šefildas, Jungtinè Karalystè. Archit. Jefferson Sheard Architects (a); „Juodasis deimantas" - Karališkoji biblioteka, Kopenhaga, Danija. Archit. schmidt hammer lassen K/S, 1999 m. (b); Prokuratūru pastatas, Vilnius. Archit. K. Lupeikis, 2008 m. (c)

Fig. 17. SoundHouse, Sheffield, United Kingdom. Arch. Jefferson Sheard Architects (a); "Black Diamond" Royal Library, Copenhagen, Denmark. Arch. schmidt hammer lassen K/S. 1999 (b); Prosecutor's Office Building, Vilnius. Arch. K. Lupeikis, 2008 (c) 

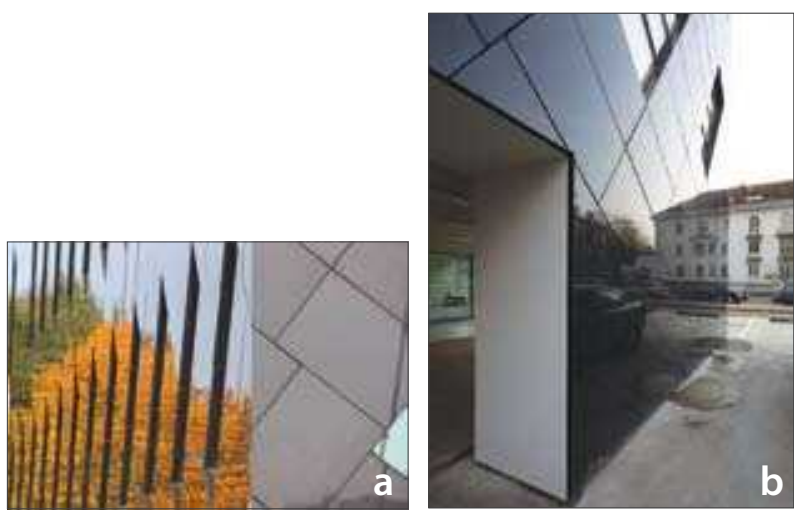

18 pav. Prokuratūrų pastatas (atspindžiai) (a, b), Vilnius. Archit. K. Lupeikis, 2008 m.

Fig. 18. Prosecutor's Office Building (reflections) $(a, b)$, Vilnius. Arch. K. Lupeikis, 2008.

gomis. Stogai - sutapdinti, plokšti. Fasadas - metalinè struktūra su klijuojamomis $2 \mathrm{~cm}$ storio granito plokštèmis, ventiliuojamas. Fasadams įrengti prireikè itin aukštos darbo kokybès ir tikslumo. Pasvirusių langu technologija Lietuvoje yra pritaikyta pirmąji kartą. Juos montuojant reikejo didelio kruopštumo, nes nuo šio darbo kokybès priklausè teisingas fasado granito plokščių sumontavimas. Granito plokštès ir langai tikslių matmenų, todèl langų konstrukcijų ašis reikejjo nustatyti ypač tiksliai. Vidaus pertvaros - gipso kartono sistemos, stiklas, stiklo blokeliai. Vèdinimas - natūralus, per langus, ir mechaninis, oro kondicionavimo sistema. Irengta gaisro gesinimo sistema, signalizacija etc.

\section{Juodojo kubo „siela“}

KONCEPCIJA. Administracinio Prokuratūrų pastato architektūrinè bei plastinè ideja - kubas - konceptualiai ịprasmina tvarką, stabilumą, tvirtumą, griežtumą ir pan. Nuo pirmųjų idejjos paieškos akimirkų buvo aišku ir iki pat galo nekilo nei menkiausių abejonių, kad „prokurorų namas" turi būti kubas (20 pav.).

Kubas turi tobulumo kodą ir geriausiai atspindi objekto specifiką. Tai labiausiai tinkama forma, ji sukuria išskirtinai įtaigų, koncentruotą teisètvarkos institucijos įvaizdị.

Tačiau kai kurie architektūros teoretikai ir kūrèjai, tokie kaip J. Kipnis, G. Lynn, Future Systems bei Oosterhuis, siūlo ieškoti architektūrinių formų, atitinkančių šiuolaikinio pasaulio dinamiškumą. Siekiama sukurti vizualinị judèjimą arba tokias architektūros
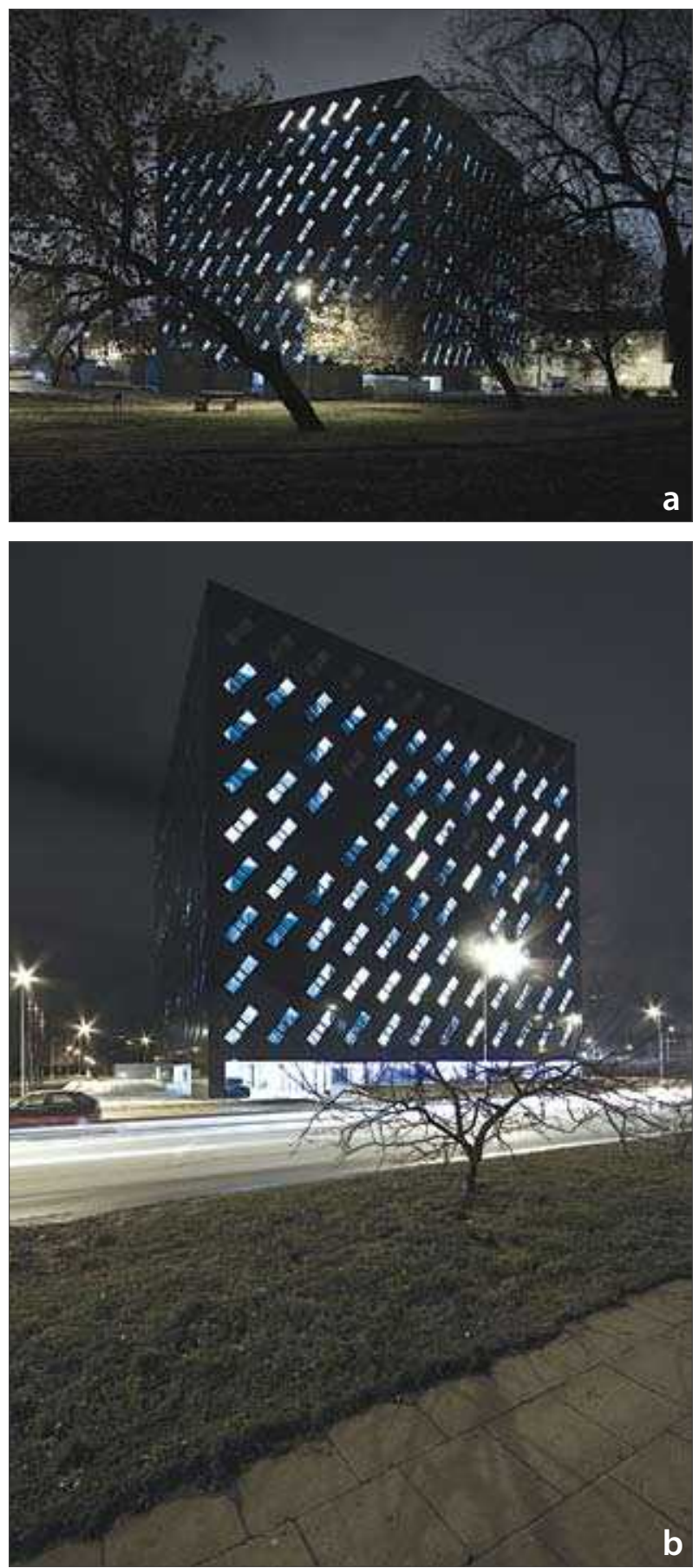

19 pav. Prokuratūru pastatas nakti $(a, b)$, Vilnius. Archit. K. Lupeikis, 2008 m.

Fig. 18. Prosecutor's Office Building at night $(a, b)$, Vilnius. Arch. K. Lupeikis, 2008 

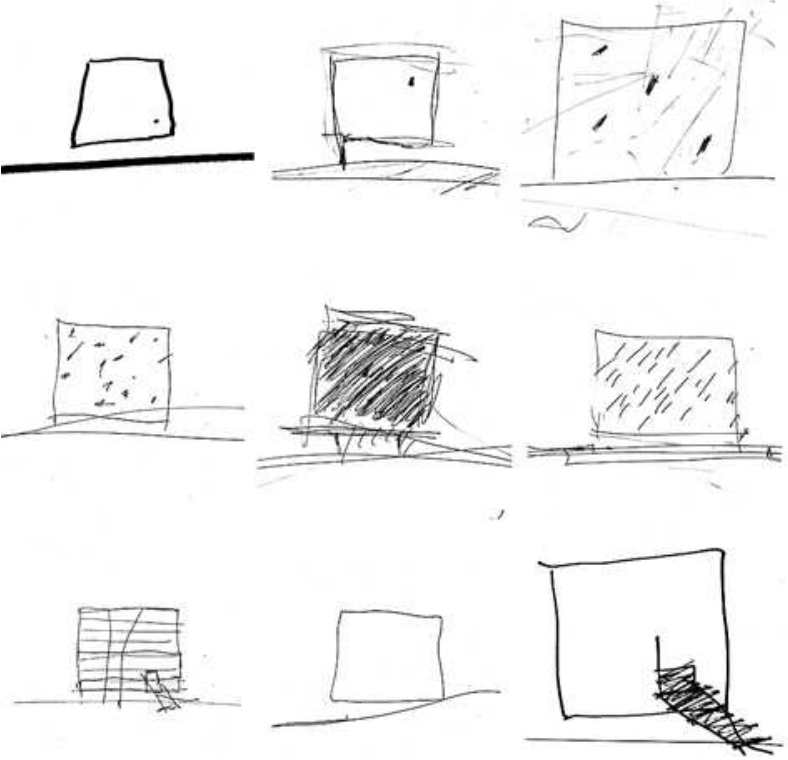

20 pav. Prokuratūru pastato eskizai, Vilnius. Archit. K. Lupeikis, 2004 m.

Fig. 20. Prosecutor's Office Building sketches, Vilnius. Arch. K. Lupeikis, 2004

formas, kurios būtų plastiškos, grakščios ir lanksčios. Savo ese „Forma ir laukas“ (Form and Field) G. Lynn irodinejja, kad „<...> atsižvelgiant ị šiais laikais vykstančius materialius ir nematerialius struktūros pokyčius, architektūra privalo tapti gyvesnè - ji privalo judetti!“ „Klasikinès išgrynintos, statiškos, esmingos ir nesenstančios formos bei konstrukcijos modeliai jau nebegali adekvačiai atspindèti šiuolaikinio miesto dvasios ir ją palaikančios veiklos" (Speaks 1998: 28).

Griežtos geometrijos, asketiško juodo kubo formos tūrio kompoziciją konceptualiai papildo pasvirusių langų ritmika, kuri monumentaliam, statiškam pastato pobūdžiui suteikia veržlumo, dinamiškumo, o tai yra neatsiejama prokuratūros veiklos pobūdžio dalis. Taip sunkiai, itin stabiliai formai suteikus dinamikos elementų, bendroje kompozicijoje atsiranda vizualinis judejimas, kaita, ketvirtoji dimensija, statiška forma igyja jai nebūdingų savybių, aktyvuojasi ir tampa hiperpaviršiumi. Tai yra vienas iš būdingiausių pirminès geometrijos formos virtimo hiperpaviršiumi atvejų. Čia „,_..> hiperpaviršiaus reikšmès iggauna kultūrinę, egzistencinę prasmę, keičia matematinį hiperpaviršių suvokimą. Naujojoje hiperpaviršiaus prasmejje hipersu paviršiumi nesudaro binarinio santykio, tai naujas supratimas, kuris mūsų šiuolaikiniame realiame pasaulyje apibūdina kompleksišką architektūrinių paviršių būklę" (Lupeikis 2007:163).
Vienas iš svarbesnių pastato įvaizdžio formantų, koncepcijos dalis - išorinei apdailai naudojamas juodas, poliruotas granitas, kuris, kaip natūrali, tauri medžiaga, turi pabrèžti vienai iš svarbiausių teisètvarkos institucijų būtiną solidumo lygị. Ji objektą apgaubia tarsi juoda mantija prokurorą. Kartu ši natūrali ir tauri medžiaga statiniui suteikia būtiną prestižo lygí. Juoda spalva - teisètvarkos spalva - konceptualiai papildo bendrą pastato sprendimą (šiuo atveju kokia nors kita spalva būtų paprasčiausias formalus estetizavimas, gražaus "grožio“ ieškojimas, o tai nesuderinama su objekto specifika).

KONTEKSTAS. Kiekvienas architektūrinis objektas neišvengiamai egzistuoja tam tikrame kontekste, kuris daugiau ar mažiau veikia bet kokią architektūrinę raišką. Šiuo atveju išskirtini trys pagrindiniai konteksto tipai: gamtinis, urbanistinis ir kultūrinis.

Minimalistinis požiūris ị kontekstą, o „Juodasis kubas" priskirtinas šiai stilistinei pakraipai, yra gana specifinis. Remiantis daugelio pavyzdžių analize galima teigti, kad minimalistams daug labiau rūpi paties architektūrinio objekto formos grynumas, aiškumas, proporciju tobulumas, meditatyvumas negu to objekto masteliškumas ir sklandus iterpimas i kontekstą, o ypač ị urbanistinị audinị. Minimalistiniai objektai savo urbanistiniu sprendimu, forma, dydžiu, medžiaginėmis savybèmis dažniausiai kontrastuoja su aplinka (21 pav.).

Tai, be abejo, nèra absoliučiai kategoriška nuostata, nes egzistuoja ir tokia kryptis kaip kontekstualusis

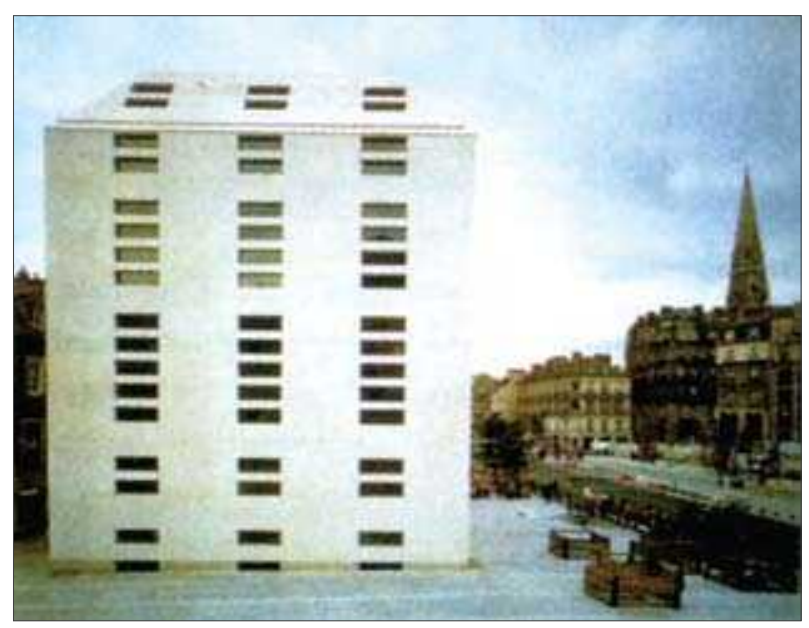

21 pav. La Perouse viešbutis, Nantas, Prancūzija. Archit. Barto \& Barto, 1994 m.

Fig. 21. La Perouse Hotel, Nantes, France. Arch. Barto \& Barto, 1994 
minimalizmas, o iš esmès kitų minimalizmo krypčių atstovų darbuose galima pastebėti gana taktiškų sprendimų senamiesčio ir kitokio susiformavusio užstatymo konteksto atžvilgiu.

Gamtinis kontekstas labai sèkmingai integruoja švarias, aiškias, lakoniškas minimalistines formas. Minimalistai žavisi didelèmis, tuščiai atrodančiomis erdvèmis, kurias užlieja šviesa, ir labai dažnai siekia šiuos elementus perkelti $\mathfrak{x}$ savo projektus. Šiuo atveju gamtinis kontekstas - dirbtinai suformuotas skveras, žalia veja su pavienėmis grupėmis želdinių, švelnus reljefas. Buvo siekiama sklandžiai ịsilieti ị šią aplinką.

Urbanistinis kontekstas - stichiškai susiklosčiusi, atsitiktinè miesto audinio struktūra. Dominuoja $\mathrm{XX}$ a. pirmos ir antros pusès standartinis, neunikalus, menkavertis užstatymas - tipinè sovietinių laikų gyvenamoji statyba. Šis kontekstas - neįpareigojantis. Vienintelis dalykas ị ką buvo reaguojama - tai išlaikoma Rinktinės gatvės užstatymo linija, kaip charakteringas aplinkinio užstatymo veiksnys. Kvartalo gilumoje stovintys sovietinès statybos tipiniai daugiabučiai neturi jokios architektūrinès vertès ir neveiké pastato idejos formavimo (22 pav.).
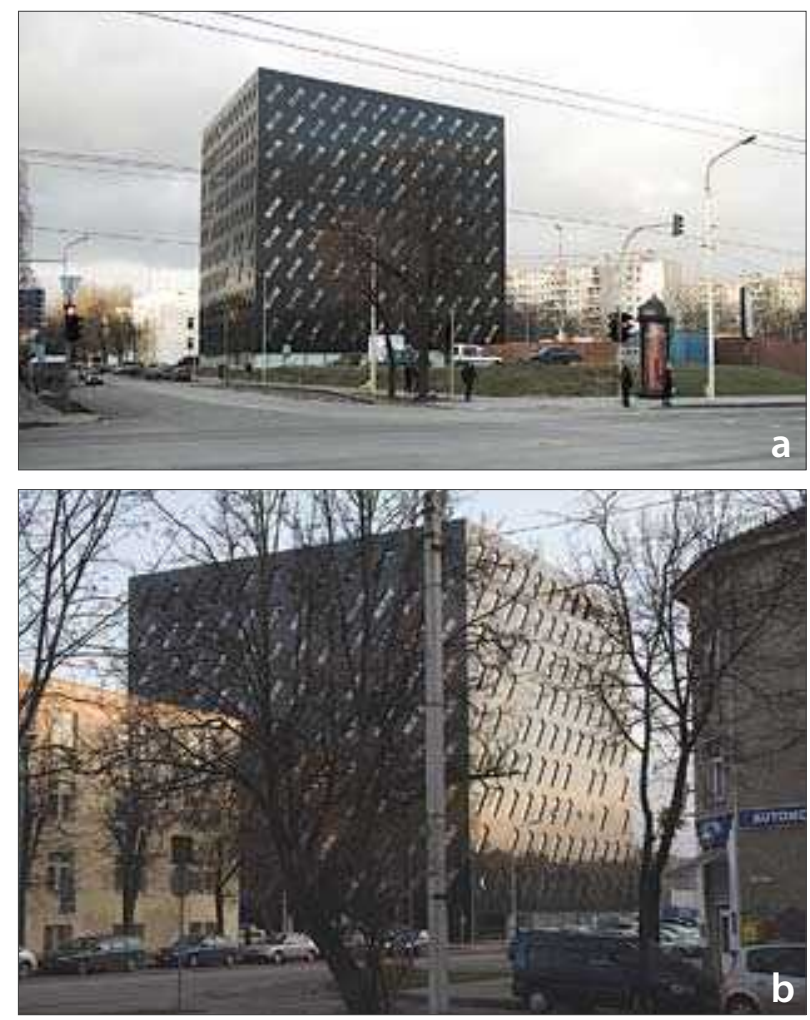

22 pav. Prokuratūru pastatas (kontekstas) (a, b), Vilnius. Archit. K. Lupeikis, 2008 m.

Fig. 22. Prosecutor's Office Building (context) $(a, b)$, Vilnius. Arch. K. Lupeikis, 2008
Kultūrinis kontekstas taip pat turi įtakos minimalistinei raiškai ir formai. Tai asketiškumo, sietino su japonų dzen ir cistersų vienuolynų tradicijomis, elitiškumo, kylančio iš dabartinès prabangos ir intelektualumo sampratos, sudvasinto praktiškumo, stengiantis pasinaudoti mokslo ir technologijų laimèjimais, siekiai. „Juodojo kubo“ kultūrinis kontekstas siejamas su vietos tradicijomis, religija, politika, socialine sfera, mokslu ir technine pažanga. Ypatingą itaką šiuo atveju turèjo objekto paskirtis ir jo vaidmuo socialiniame bei politiniame kontekste.

L. Markejevaitè, apibendrindama meninès formos ir konteksto ryši, teigia: „,...> konteksto, ị kurị iterpiamas architektūrinis objektas, savitumai yra vienas pagrindinių impulsų, skatinančių kurti daugiareikšmę ir prasmingą architektūros kūrinio meninę formą. Gamtinio, urbanistinio ir kultūrinio kontekstų susipynimas, daugiasluoksniškumas lemia kompleksinių sprendimų paiešką, sudaro sąlygas visapusiškai atsiskleisti formą tektonizuojantiems elementams: meniniam pavidalui, konstrukcinei sandarai ir medžiagai“" (Markejevaitè 2003: 89). Šiuose teiginiuose išryškejja mintis, kad ịvardyti kontekstų tipai nẻra atskirai veikiantys, jie yra susiję ir sudaro sudetingą kompleksą. Tiesa, kiekvieno konteksto tipo lyginamasis svoris kontekstų visumoje dažniausiai yra nevienodas. Administracinio Prokuratūrų pastato idejją veikè gamtinis bei kultūrinis kontekstas ir tik iš dalies urbanistinis.

Prioritetas šiuo atveju buvo teikiamas tikslui išreikšti specifinę prokuratūros, kaip institucijos, aurą, paties architektūrinio objekto meninei kokybei, idejjos ir formos grynumui, aiškumui, proporcijų tobulumui, itaigumui, o ne jo masteliui ar sklandžiam įterpimui i aplinką. ,Prokurorų namas“ forma, dydžiu, medžiaginėmis savybėmis kontrastuoja su aplinka. Buvo siekiama kokybiško meniškai konceptualaus rezultato, o ne pataikavimo aplinkai, ištirpimo joje. „Juodasis kubas“ tarsi išreiškia norą išsiskirti iš aplinkos, nesusilieti su aplinkiniu pilkų pastatų užstatymu ir suteikti teritorijai naują tonaciją, skambesị. Darbo moto: jei rezultatas yra kokybiškas, tai nesvarbu, ar architektūrinis objektas niuansuoja, ar kontrastuoja su aplinka, ji nèra sugadinama, o iggauna naują, geresnę kokybę.

„Juodasis kubas" iš arti atrodo užgožiantis, „valgantis" aplinką, dominuoja aplinkinio užstatymo atžvilgiu. Tačiau bendrame viso miesto ar šios mieto dalies kontekste neatrodo agresyviai (stebètojų nuomonè). Dèl savo juodumo jis lyg ,juodoji skylè“ tampa sun- 
kiai pastebimas, lyg pauzè juodu tašku ịkūnijanti tylos paieškas miesto triukšme.

IŠRAIŠKA. Minimaliom priemonèm siekiama maksimalaus ịtaigumo, išraiškingumo. „Less is more“ (Ludwig Mies van der Rohe). Naudojant minimalias išraiškos priemones buvo siekiama sukurti naujo administracinių įstaigų tipo pastatą. Projekte buvo atsisakyta U, L ar T formos konfigūracijų, ịprastų administraciniams pastatams, ir pasirinkta baigtinè, uždara kubo forma. Virš skaidraus įstiklinto cokolinio aukšto „pakibęs" masyvus juodas kubas pabrèžia stabilų, tvirtą, lyg uola nepajudinamą teisèsaugos institucijos ịvaizdį. Pastatas vizualiai sklendžia ir baugina... (23 pav.).

Psichologinio poveikio elementai buvo naudojami formuojant pagrindinị įejimą. Jis yra šiek tiek ịgilintas, o jo proporcijos sąmoningai suformuotos taip, kad pasąmoningai kiltų noras pasilenkti ir ịstaigos lankytojus apimtų tam tikra baimès bei pagarbumo būsena (24 pav.).
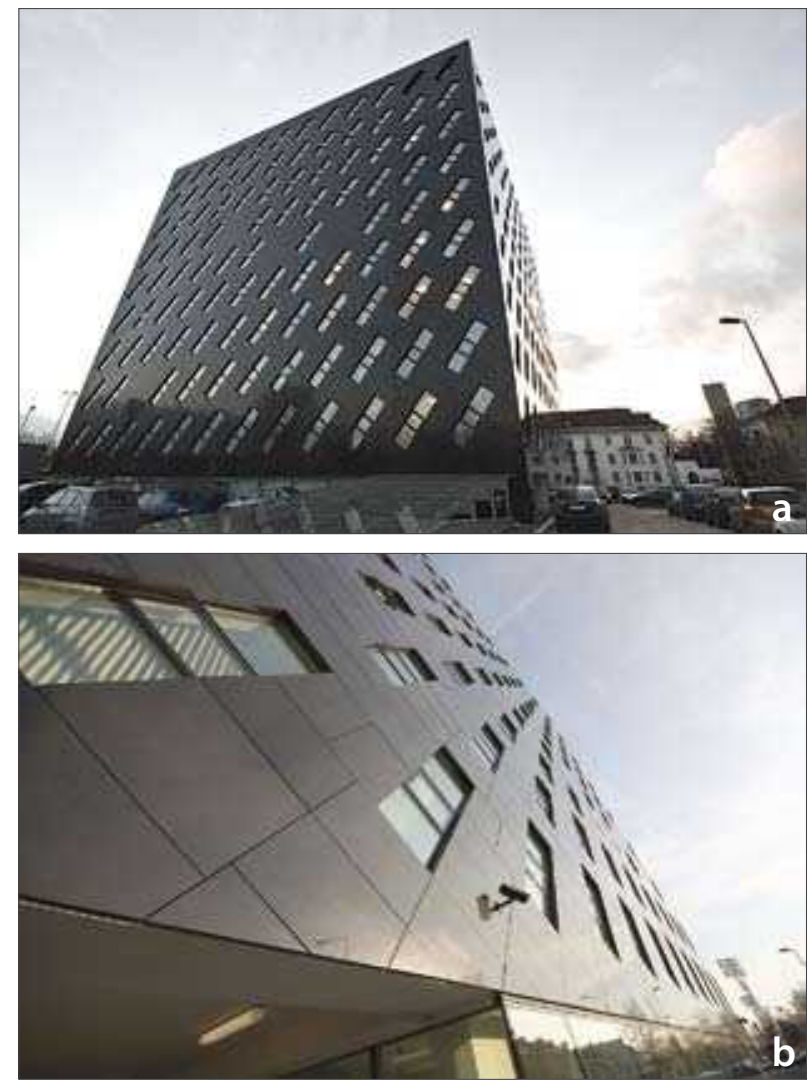

23 pav. Prokuratūru pastatas iš arti $(a, b)$, Vilnius. Archit. K. Lupeikis, $2008 \mathrm{~m}$.

Fig 23. Prosecutor's Office Building close up $(a, b)$, Vilnius. Arch. K. Lupeikis, 2008

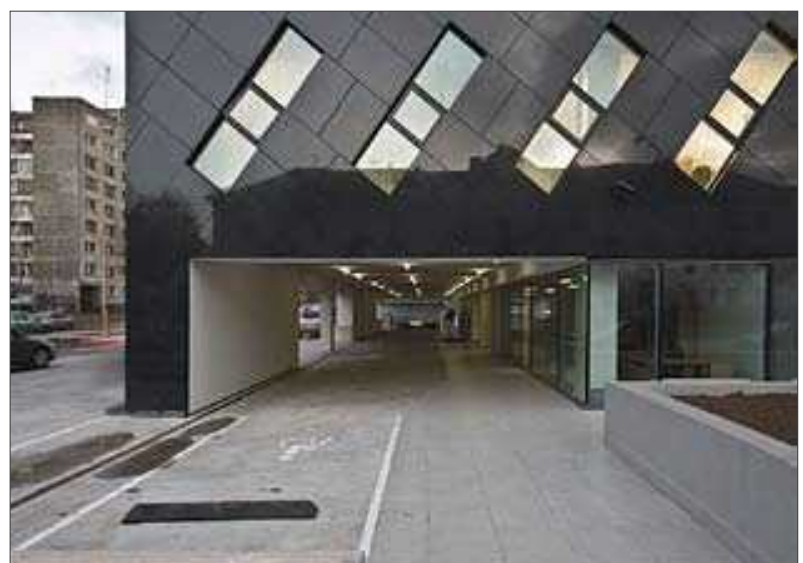

24 pav. Prokuratūru pastato pagrindinis jejjimas, Vilnius. Archit. K. Lupeikis, $2008 \mathrm{~m}$.

Fig. 24. Prosecutor's Office Building main entrance, Vilnius. Arch. K. Lupeikis, 2008

Kuriant ši naują neịprastos formos administracinị Prokuratūrų pastatą buvo naudojamos netradicinès meninès raiškos formos. Juodas kubo formos statinys tarsi „žaidžia“ su erdve, laiku ir minimalistiniu stiliumi. Naudojant nestandartinius architektūrinius sprendimus buvo siekiama, kad griežta pastato forma suskambètų tarsi nauja architektūrinè tonacija. Čia susilieja griežtumo, paprastumo ir santūrumo sąskambiai. Tikslas - originalus objekto pavidalas, kuris vaizdžiai atspindètų teisètvarkos institucijos, o ne santuokų rūmų pobūdị, sukurtų tvirtą bei įtaigų jos ịvaizdį ir nepataikautų biurgeriškai miestelènų pasaulèžiūrai. Natūralu, kad demokratinèje visuomenèje, kurioje galioja žodžio laisvè, šios idèjos sukẻlè plačią diskusiją visuomenèje. Pastatas neliko nepastebètas, o to ir buvo siekta.

\section{Apibendrinimai}

Straipsnyje aptartas toli gražu ne visas pirminių formų raiškos spektras. Buvo nagrinèti, autoriaus manymu, charakteringiausi šios raiškos atvejai, daugiausiai dėmesio skiriant Prokuratūrų pastato - „Juodojo kubo" - morfologijai. Tuo remiantis galima padaryti šiuos apibendrinimus:

1. Pirminių minimalistinių formų raiška šiuolaikinëje architektūroje gana populiari. Nors neretai sukelia prieštaringas diskusijas visuomenejje, tačiau net oponentai neneigia jos įtaigumo ir paveikumo, nes ji padeda artèti prie tikrujų vertybių, esmès. 
2. Minimalių pirminių formų naudojimas išryškina tokias estetines vertybes kaip paprastumas (ne prastumas), aiškumas, grynumas etc. Atsiskleidžia specifiniai minimalistinès raiškos šiuolaikinèje architektūroje tikslai: su „mažiau“ siekiama „daugiau“, per natūralų paprastumą siekiama tobulumo, harmonijos, poezijos pragmatizme.

3. Remiantis nagrinètais pavyzdžiais galima teigti, kad urbanistinis kontekstas minimalistinę raišką veikia santykinai nedaug. Minimalistiniai objektai savo urbanistiniu sprendimu, forma, dydžiu, medžiaginèmis savybėmis dažniausiai kontrastuoja su aplinka. Pirminès formos tiesiog skamba gamtiniame kontekste, o ypač konceptualiai veikia kultūrinis kontekstas. Lemiamas formantas Prokuratūrų pastato atveju - objekto paskirtis ir jo vaidmuo socialiniame bei politiniame kontekste.

4. Pagrindines kompozicines priemones jungia forma, kuri, kaip kompozicinè priemonè, geriausiai išreiškia minimalistinès raiškos ypatybes. Forma - minimalistinès raiškos specifiką lemiantis veiksnys.

5. Lemiamos reikšmès pirminių formų evoliucijai turi hiperpaviršiu mokslinės teorijos ir šiuolaikinès jų interpretacijos. Prokuratūrų pastato pavyzdys pateiktas kaip pirminès formos transformavimo ị hiperpaviršių teorinis pagrindimas. Pirminès formos gali būti laikomos hiperpaviršiais, jeigu jos atitinka pamatinius hiperpaviršių morfologinius principus.

6. Pirminès formos šiuolaikinejje architektūroje keičia stereotipą apie save, transformuojasi, tampa dinamiškos ir yra lankstus, sparčiai evoliucionuojantis šiandienos kūrybinio arsenalo veiksnys.

7. Pirminių formų raiška tai fenomenas, neturintis apibrèžtų tiek chronologinių, tiek geografinių ribų, ji galima interpretuoti tiek sakraliu, filosofiniu, tiek ir buitiniu požiūriu.

\section{Literatūra}

Adomonis, J. 1994. Nuo taško iki sintezès. Vilnius: Dailès akademijos leidykla. $175 \mathrm{p}$.

Baltrušaitytè, R. 2009. Architektas stengèsi, kad pastatas keltų pagarbią baimę, Veidas 4: 50-51.

Becker, U. 1995. Simbolių žodynas. Vilnius: Vaga. 323 p.

Buivydas, R. 1995. Ezoterinis simbolių žodynas. Vilnius. 264 p.

Burneika, J. 2002. Forma, kompozicija, dizainas. Vilnius: Dailès akademijos leidykla. $142 \mathrm{p}$.

Grinius, J. 2002. Grožis ir menas. Vilnius: Mintis. 553 p.

Jarmalis, S. 2008. Prokurorų būstinè - juodas kubas, Būstas. Lietuvos rytas 47: 8-9.
Kšivickaitė, J. 2008. Prokuratūrų administracinis pastatas, Archiforma 3-4: 40-43.

Leitanaite, R. 2004. Juodos tiesos prokurorai nebijo, Statybu pilotas 8: 1,6 .

Leitanaitè, R. 2006. Juodos tiesos prokurorai nebijo, Statybu pilotas 6: 1,7 .

Leitanaitè, R. 2008. Juodos tiesos prokurorai nebijo, Statybu pilotas 9: 1, 4-5, 9 .

Levandraitytè, M. 2008. Juodasis kubas - individualistas, Statyba ir architektūra 10: 27-31.

Lupeikis, K. 2007. Minimalizmo galia. Vilnius: Technika. $192 \mathrm{p}$.

Maggie, T. 1996. Colour in Architecture/Editorial, Architectural Design 3-4: 7. London: Wiley \& Sons.

Markejevaitè, L. 2003. Erdves ir formos tektonika architektūroje bei studijose. Vilnius. $180 \mathrm{p}$.

Rubavičius, V. 2009. Akivaizdu ir ìspūdinga: teisèsaugos „juodoji skyle““ [interaktyvus] [žiūrèta 200902 10]. Prieiga per internetą: $<w w w . b a l s a s . l t>$.

Speaks, M. 1998. It's Out There, Architectural Design 5-6: 26-31. London: Wiley \& Sons.

Štelbienè, A. 2009. Juoda prokuratūros mantija, Nauja statyba 1: 20-27.

Truskauskienè, E. 2009. Naujasis drabužis, Namas ir aš 3: $70-81$.

Zamarian, P. 2009. Machtgebarden. Modulor 3. Urdorf, CH: 66-70. ISSN 1662-7741.

Zvirgzdiņš, A. 2009. Melnais kubs Prokuraturas eka Vilna [interaktyvus] [žiūrèta 200902 16]. Prieiga per internetą: $<$ www.a4d.lv>.

\section{BLACK CUBE: MORPHOLOGY AND PHENOMENON OF INITIAL FORMS}

\section{K. Lupeikis}

Abstract. Recently, alongside other phenomena, Renaissance of resort of initial forms in contemporary architecture is also observed. This process is determined by opposition to deconstructive breaking, complexity, padding. Expression of initial forms of minimalism are formed by such values as simplicity but not complexity; elegance moderation but not arrogance; spirituality but not pragmatism; essentiality but not particularity; concentration but not scatter. This scale of values determines purposes and priorities of architectural expression: "more" is sought with "less", perfection is aimed by simple means, spirituality and poetry are tried to be found in pragmatism and rationality. Resort of initial forms often evokes controversial discussions within society. Despite that even opponents do not deny their influence and impact, because initial forms enable to approach actual values, essence, whereas pluralism of opinions is publicly expressed and spontaneously is a feature of a democratic society. In the paper various aspects and areas of morphology of initial forms in contemporary architecture are discussed, marginal and distinctive cases reflecting a vast range of purposes and priorities are distinguished. It is aimed 
to reveal the essential aspects of morphology of initial forms and their phenomenon by the example of the building "Black Cube" in Vilnius.

Keywords: initial form, simplicity, minimalism, morphology, phenomenon, metamorphosis.

\section{KĘSTUTIS LUPEIKIS}

Doctor of the Humanities (arch), Assoc Prof, Dept of Architecture, Vilnius Gediminas Technical University (VGTU),

Pylimo g. 26/Traku g. 1, LT-01132 Vilnius, Lithuania. E-mail: kestl@takas.lt

First degree in Architecture, Vilnius Civil Engineering Institute (VISI, now VGTU), 1985. Teaching: architectural design, architectural composition. Membership: member of the LAS and LDS (Lithuanian Union of Architects and Lithuanian Union of Artists), member of the artist group "Angis". Projects: author or coauthor of 74 projects of architectural design. Competitions: author and coauthor of 17 projects of architectural design. Art Exhibitions: 8 personal, 26 group exhibitions. Research interests: theory of architecture, value of minimal architecture. 